\title{
المنهج النبوي لتنظيم صلاة النساء في المسجد النبوي
}

Prophetic approach on arranging Women's Prayer Space in Prophet's Holy Mosque.

\author{
سيد محمود الحسن الحن \\ الجامعة الإسلامية العالمية ماليزيا
}

Email: syedhasan89iium@gmail.com

$$
\begin{aligned}
& \text { إن الإسلام هو دين الرجال كما ادّعى المستشرقون والمبشرون. وفي تأييد هذا الإدعاء أثاروا إلى سيطرة الرجال }
\end{aligned}
$$

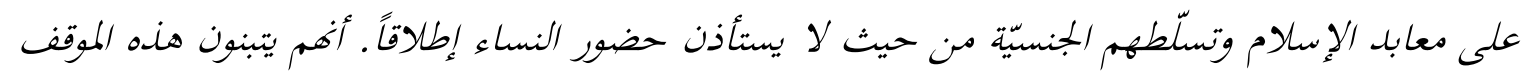

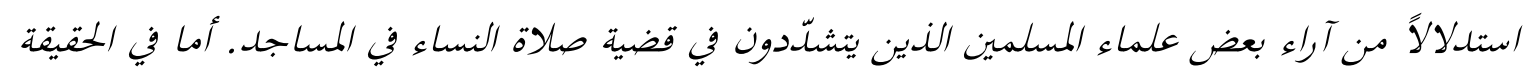

$$
\begin{aligned}
& \text { قد تخيّق الإسلام عدالة ومساواة جنسية في جميع نواحي الحياة. جعل الإسلام مشاركة النساء في صلاة الجماعة }
\end{aligned}
$$

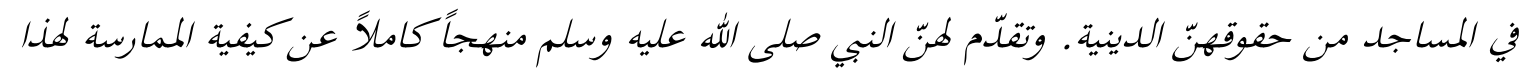

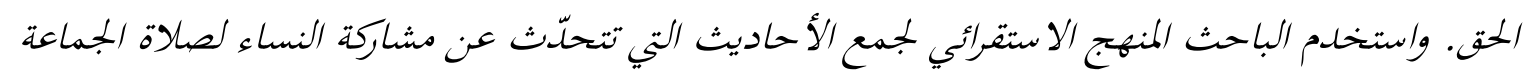

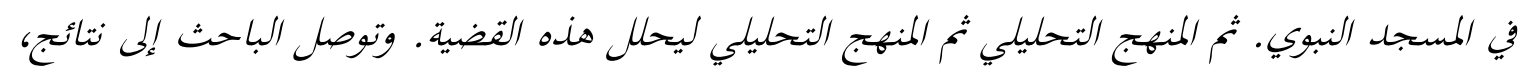

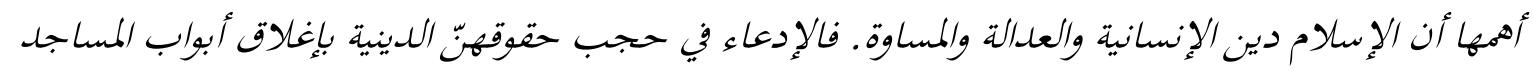

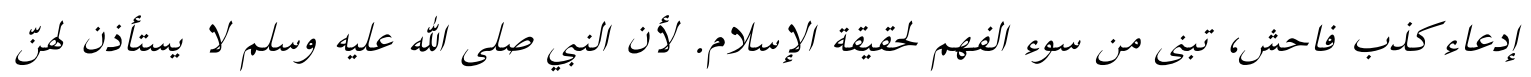

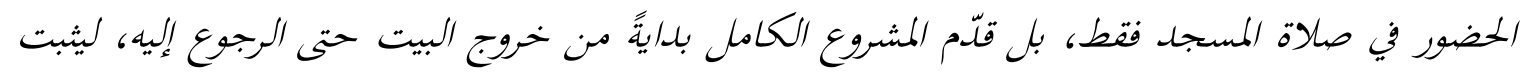

$$
\begin{aligned}
& \text { حقوق النساء وليقرّر عدالة الشريعة الإنسانية الإسلامية. } \\
& \text { الكلمات المفتاحية: } \\
& \text { المنهج النبوي، صالة النساء، المسججل، العلماء، المستشرقون. }
\end{aligned}
$$

Abstract

Islam is the religion of men, as accused by orientalists and missionaries. In support of this accusations, they referred to the domination of men over the mosques with prohibition for the presence of women at all. They adopt this position as an inference from the view of some Muslim scholars who are strict about the issue of women's prayer in mosques. In fact, Islam already achieved gender equity and equality in all aspects of life. Islam made women's participation in group prayer in mosques their religious right. The Prophet, $P B U H$, provided them with a comprehensive guide on how to practice this right. The researcher used the inductive approach to collect hadiths about women participating in group prayer in the Prophet's Mosque. Then the analytical method to analyse this issue. The researcher reached conclusions, the most important of which is that Islam is the religion of humanity, justice, and equality. The claim to withhold their religious rights by closing the doors of mosques is an outrageous lie, based on a misunderstanding of the truth of Islam. Because the Prophet, PBUH, did not only ask them to attend the mosque's prayer, but rather presented a legislation, starting from leaving the house until returning to it, to establish the rights of women and determine the justice of Islamic law.

\section{Keywords:}

The Prophetic Approach, Women's Prayer, The Mosque, Islamic scholars, Orientalists 
إن قضية صلاة النساء في المساجد قضية حساسة في مناطق بعض الدول الإسلامية. خصوصاً في دول القارة الهندية من الهند وباكستان وبنغلاديش. تحبيسهنّ من دخول المساجد ومن مشاركة النشاطات الدينية والاجتماعية هي العادة الشائعة في بعض تلك المناطق. وهذه الموقف بُني على آراء بعض العلماء المتأخرين شدّدوا في هذه المسئلة. ورجال

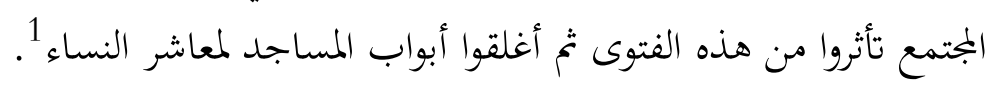

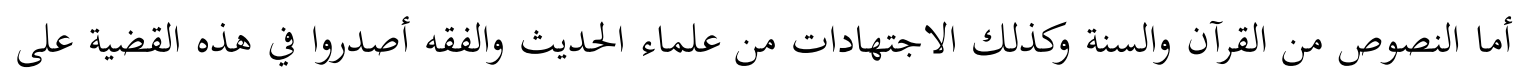
موقف إثنائي ومرونة، تتغير حسب الظروف والأحوال والأشخاص. فمن هي أهل للخروج تخرج، ومن ليست أهلاً

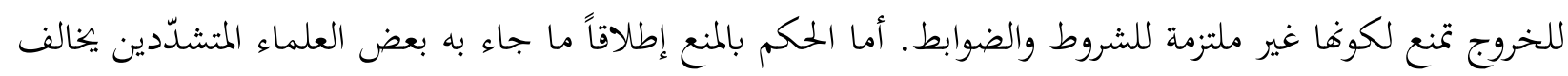

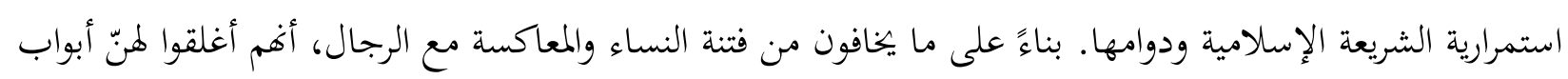
المساجد على الدوام وسلبوا حقوقهنّ الدينية. أما المنهج لنبينا صلى الله عليه وسلم في مواجهة الفتنة والانحرافات التي التي

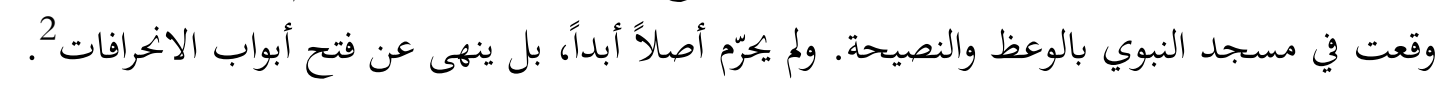

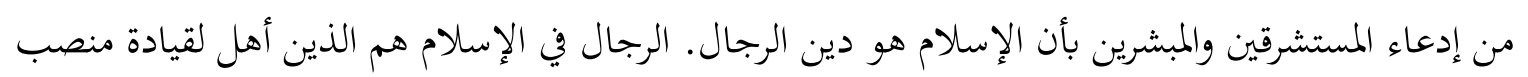

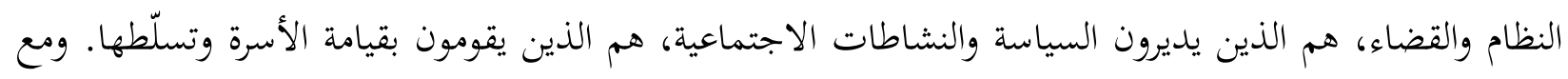

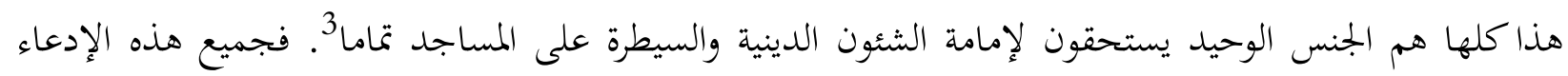
تستحق إلى دراسة علمية لكشف الحقيقة لإنسانية الشريعة الإسلامية وعدالتها. أما قضية سيطرة الرجال وتسلطّهم على المعابد والمساجد هي المحور الرئيس لهذه المناقشة العلمية. فهذه الرسالة هُدف إلى إظهار الحقيقة ببيان إهتمام النبي صلى الله عليه وسلم بحضور النساء في المساجد وكيفية تنظيم صلاكتّّ بشكل تامّ. لكي تكون إجابة عن تشديد العلماء من جهة، وعن إدعاء المستشرقين من جهة أخرى.

\section{II}

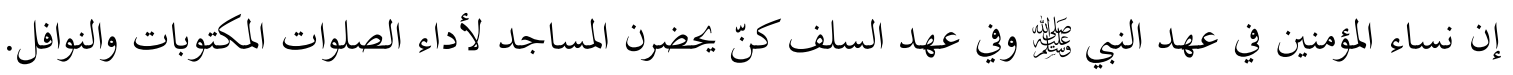

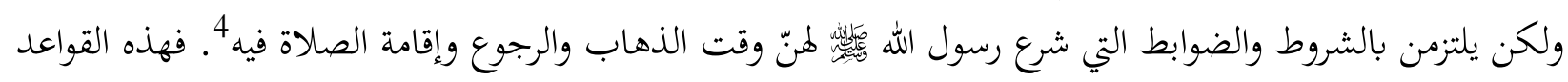

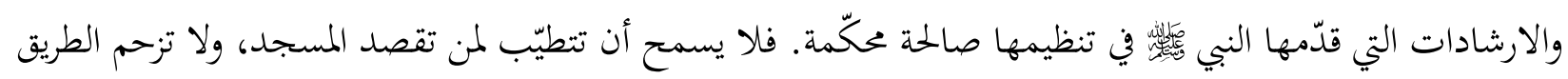

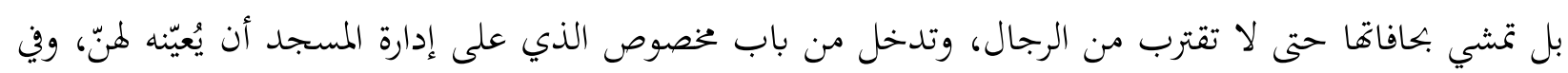

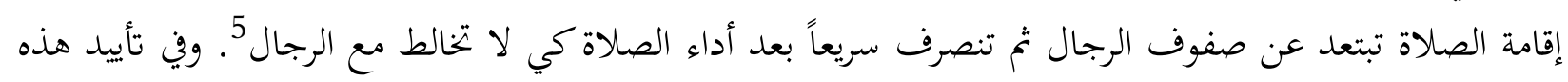

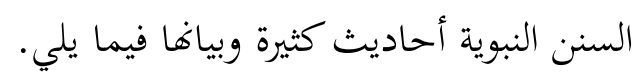

${ }^{1}$. See, Syed mahmudul hasan and Sa'duddin Mansoor, "Salat al-Nisa fi al-Masjid fi Bangladesh bayna al-Shar'I wa al-Tatbiq; Dirasah Muqarana Tahliliyyah", Journal of al-Risalah, 2,4 (2018): 139.

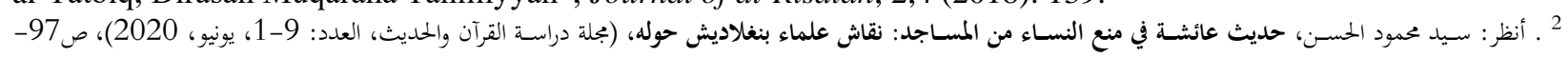

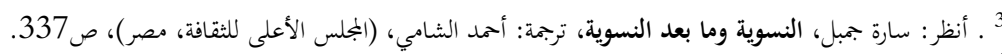

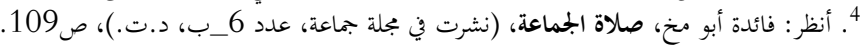

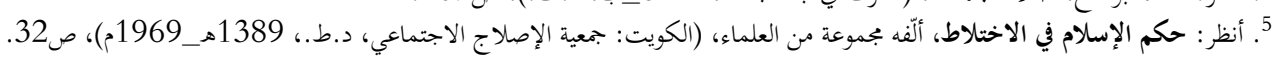

TAHDIS Volume 11 Nomor 2 Tahun 2020 


\title{
المدي النبوي المتّبعة قبل الحزوج إلى المسجد
}

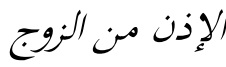 \\ قضية الإذن تدل على أمرين:
}

الأمر الأول: اتفق العلماء على ألا تخرج المرأة إلى المسجد بدون إذلى زلان زوجها، بل لا تخرج من البيت بصورة

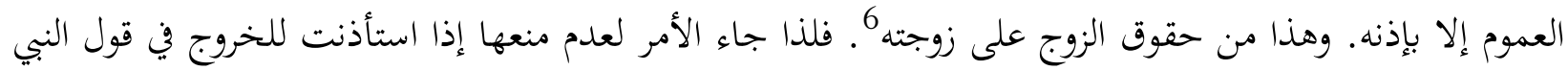

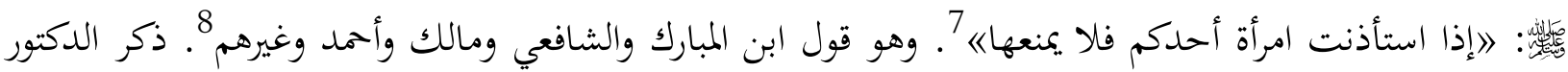

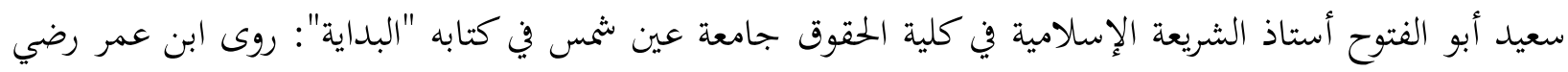

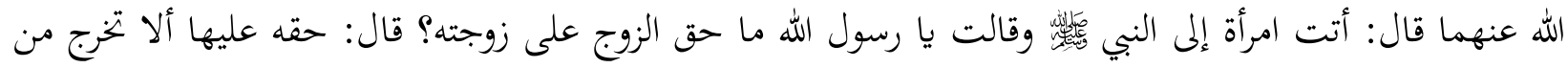

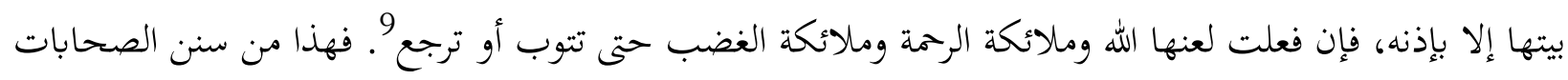

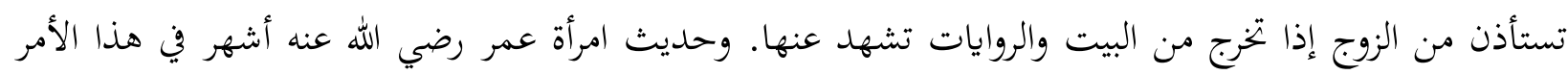

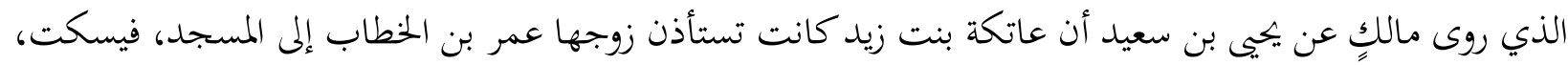

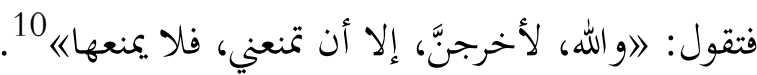

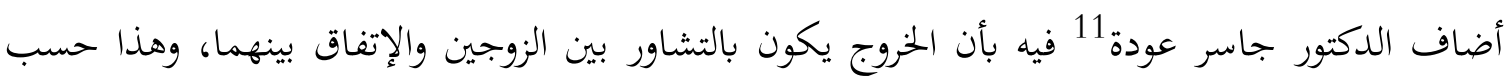

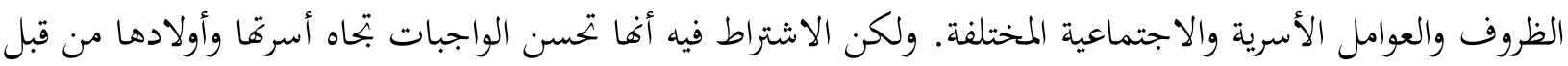

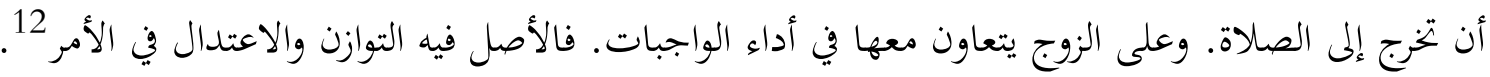

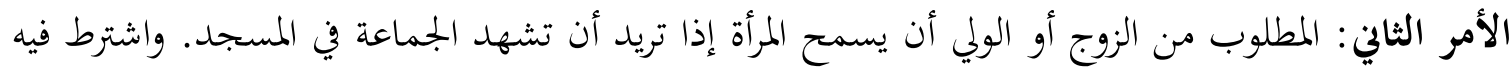

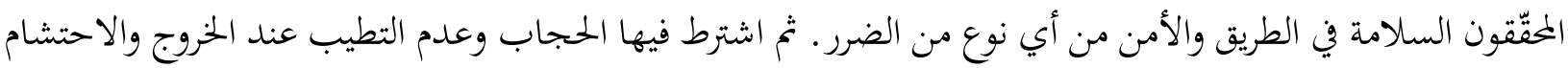

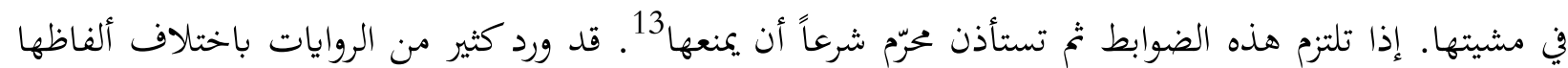

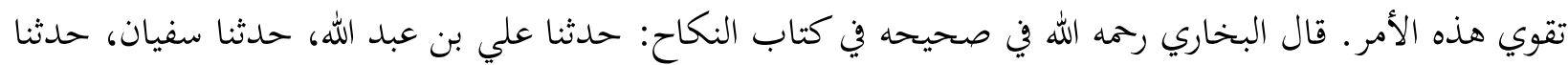

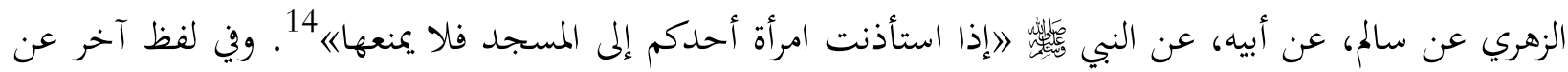

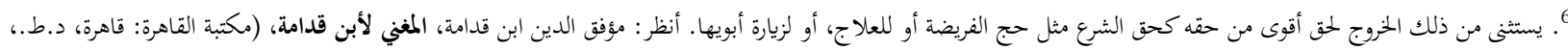

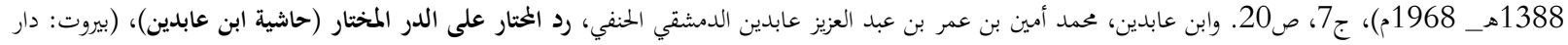

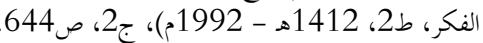

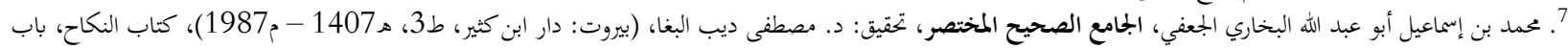

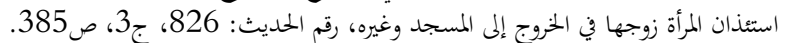

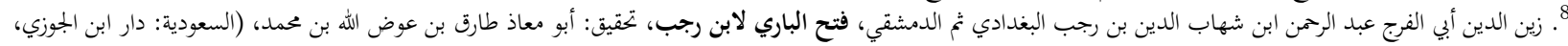

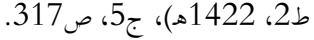

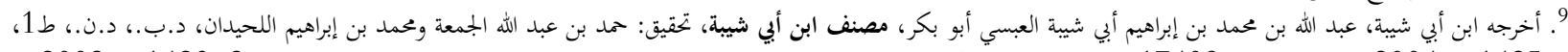

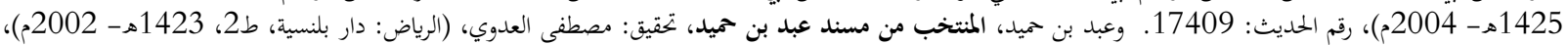

10. أخرجه مالك بن ألس 813 أنس، موطأ مالك، تحقيق: محمد فؤاد عبد الباقي، (بيروت: دار إحياء التراث العربي، د.ط.، 1406هـ-1985م)، كتاب القبلة، باب ما جاء في خروج النساء إلى

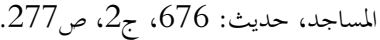

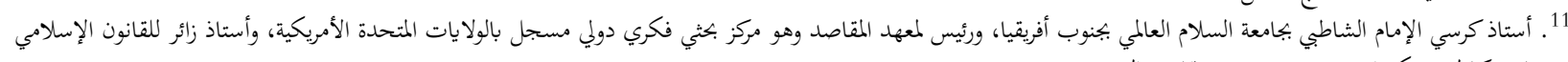

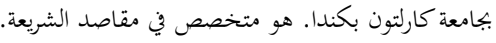

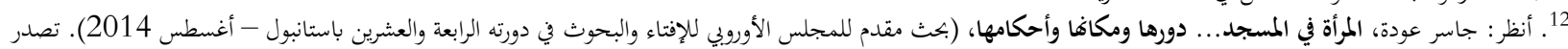

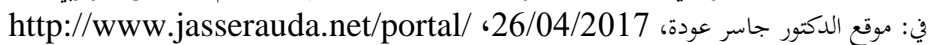

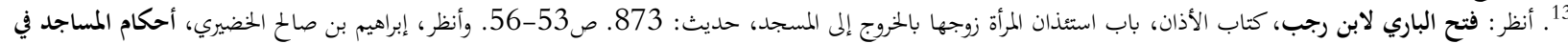

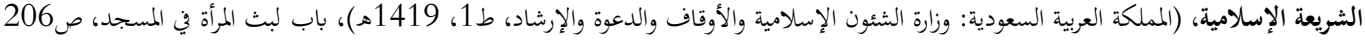

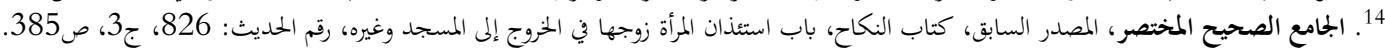




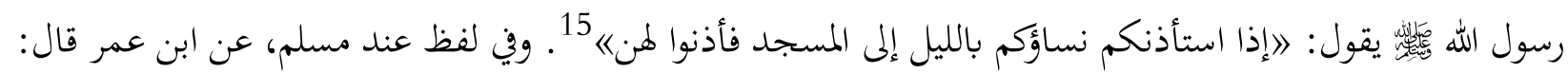

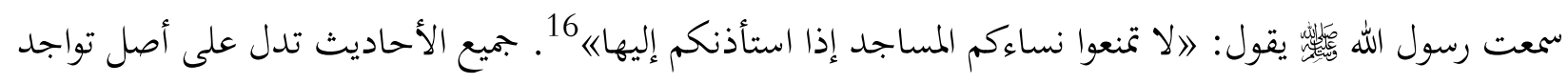
المرأة المسلمة في المسجد بكل الأشكال المشروعة وفي كل الأوقات وجميع أنواع الصلوات. ولكن الحلديث العمدة في مسألة منع النساء من المساجد هو حديث عبد الله بن عمر قال: كانت امرأة لعمر (وهي عاتكة بنت زيد) تشهد

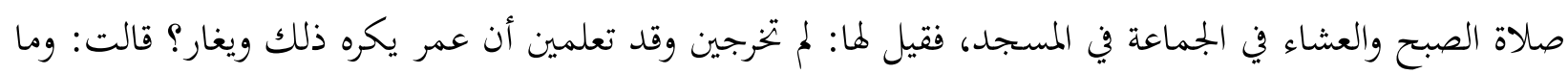

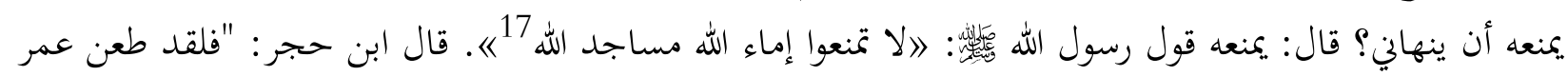
وإغها لفي المسجد"

قال النبي الأمّي كانت المسئلة في خروجها لحضور الجماعة في المسجد. فالنبي المحكم لا يسمح شيئًا يخلو من الحكمة البالغة. واختار

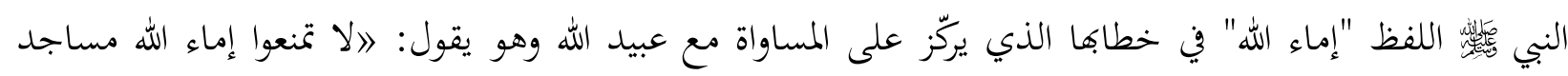

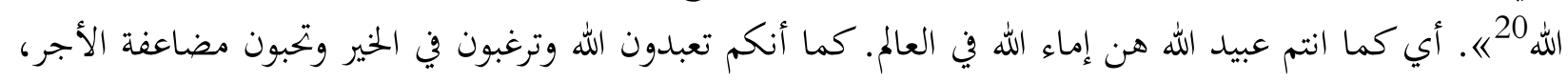
هنّ أيضاً يعبدن الله ويرغبن في الحير ومضاعفة الأجر. كلكم مماليك يساوون في العبادة والجزاء 21.

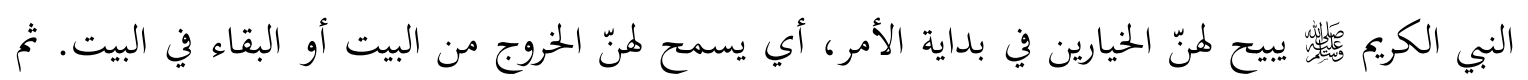

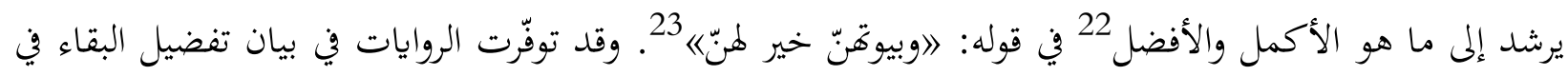

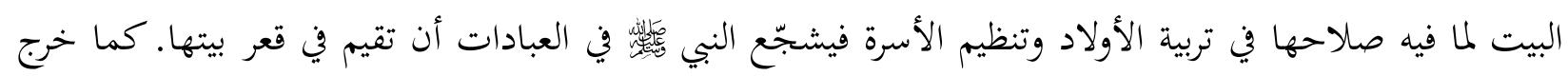

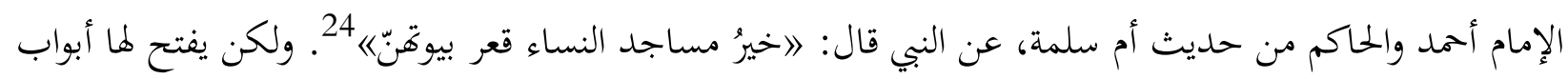

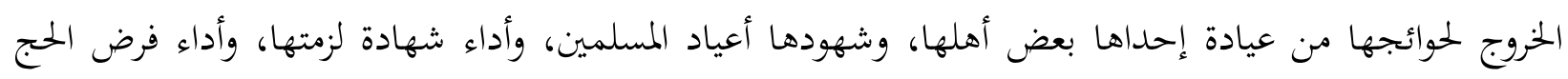

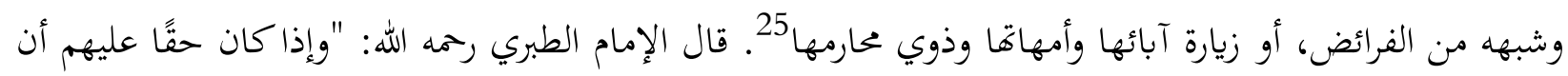

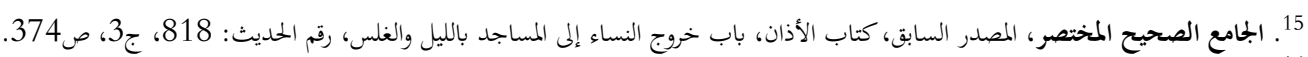

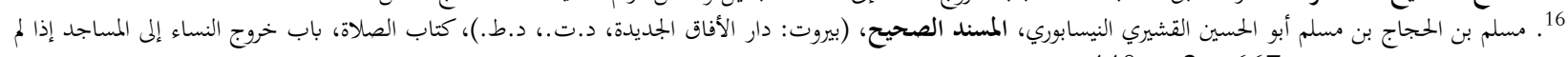

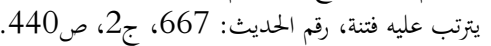

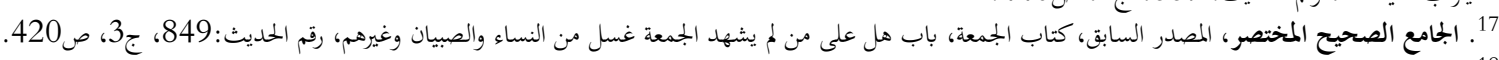

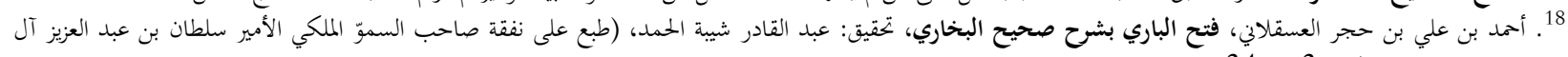

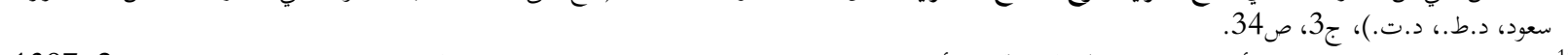

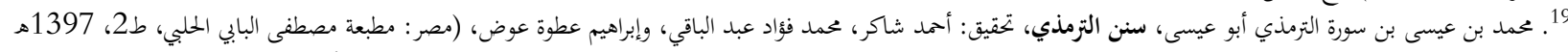

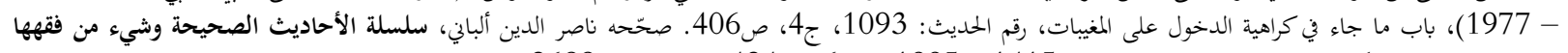

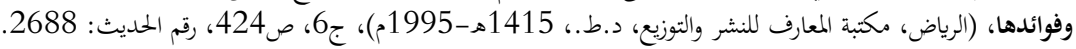

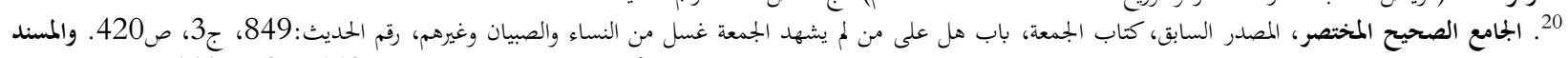

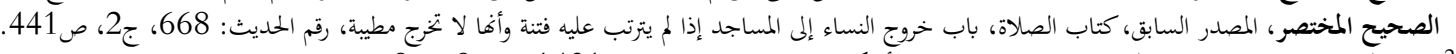

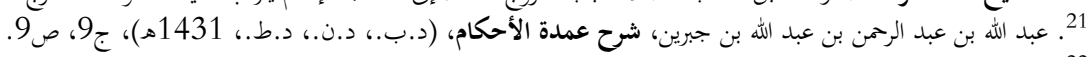

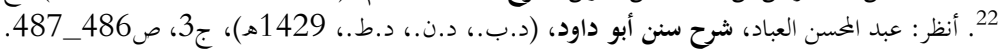

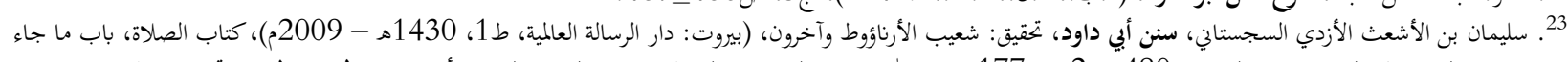

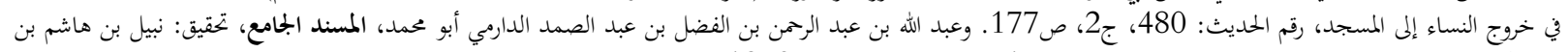

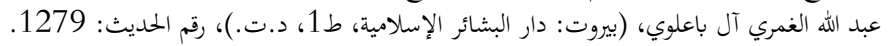

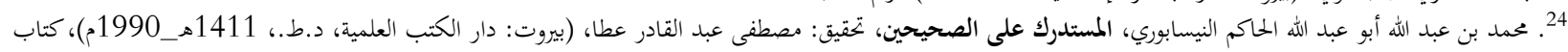

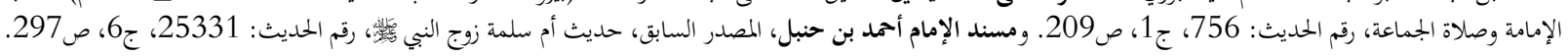

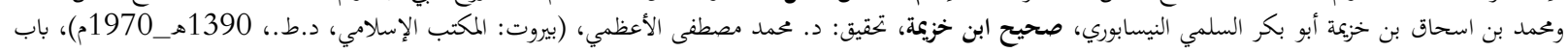

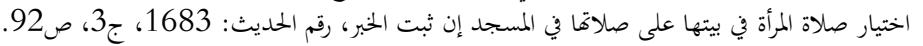

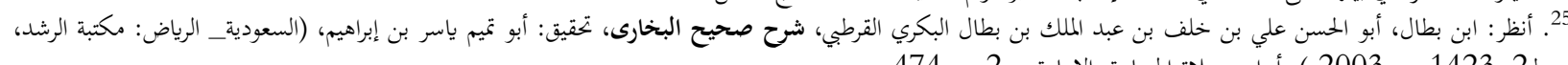


يأذنوا لهن فيما هو مطلق لهن الخروج فيه، فالإذن لهن الخروج إلى المساجد أيضا إباحة في إطلاقه عليه السلام"26. قال

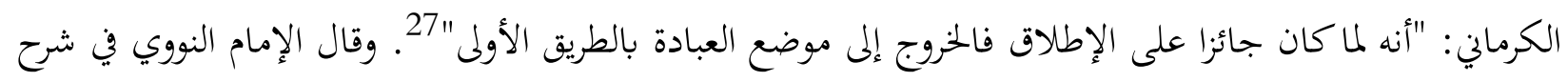

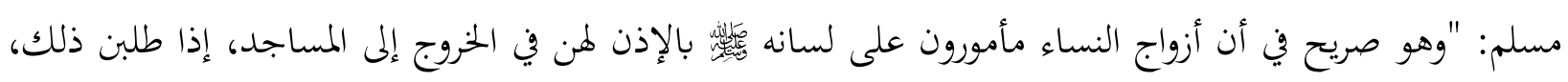
ومنهيون عن منعهن من الخروج إليها"

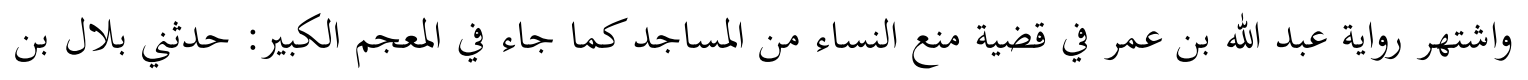

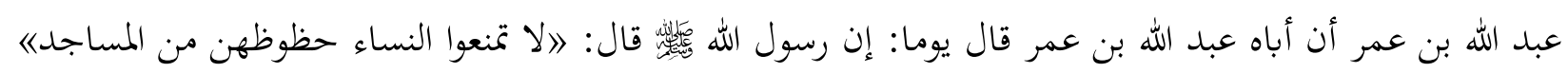
فقلت: أما أنا فسأمنع أهلي، فمن شاء فليسرح أهله فالتفت إلي، فقال: لعنك الله، لعنك الله، لعنك الله، تسمعني أقول

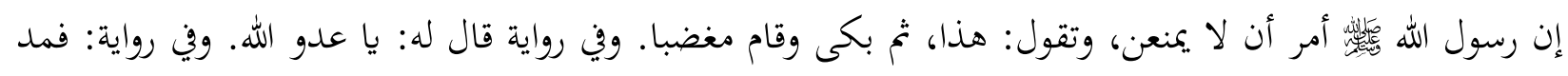

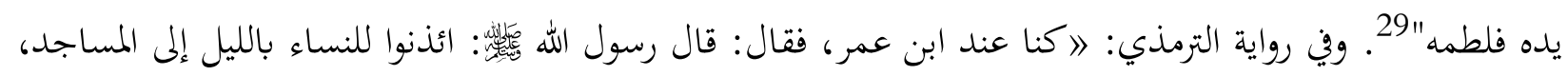

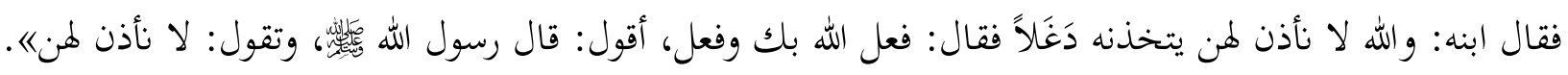

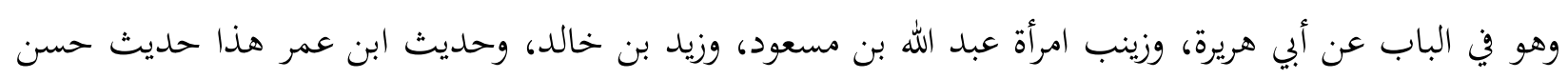

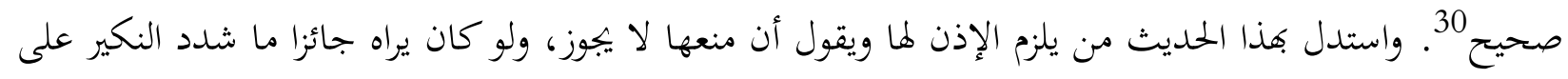

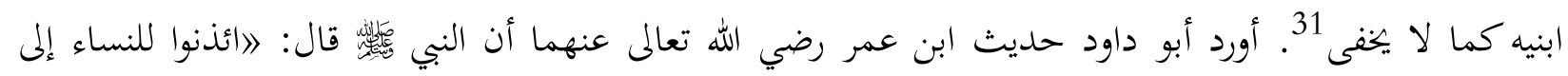

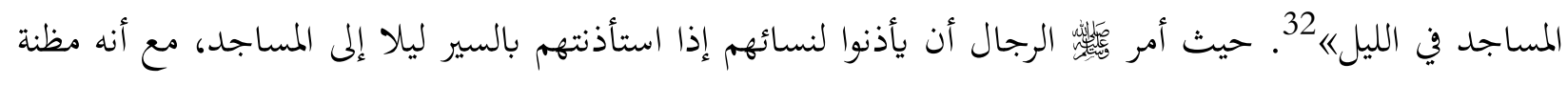

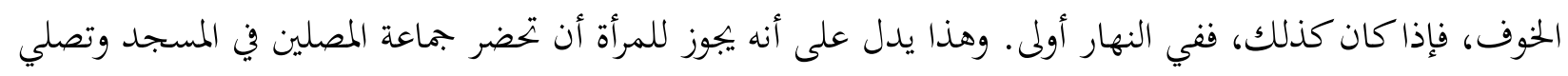

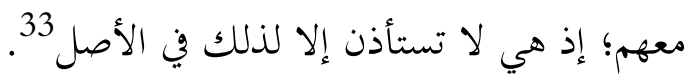
بالجملة، الأصل للمرأة هو البقاء في البيت. فإذا أرادت الخروج إلى المسجد واستأذنت يراعي الزوج طلبها

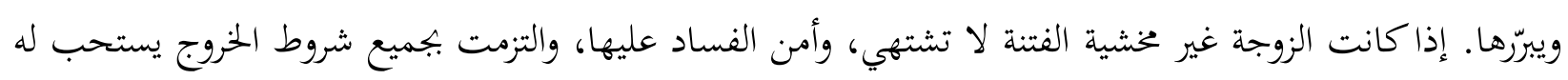

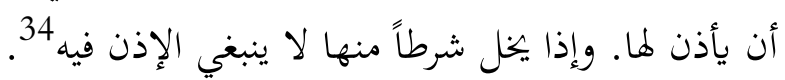

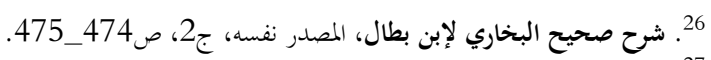

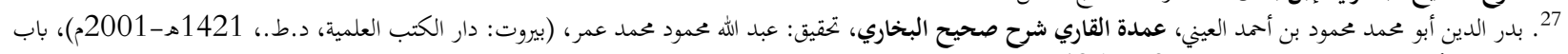

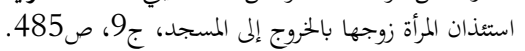

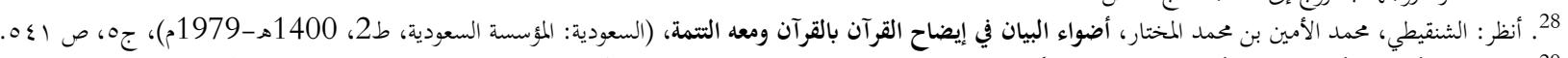

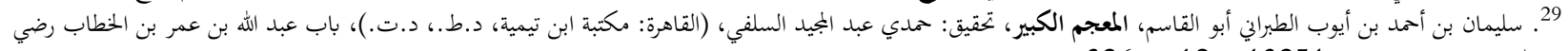

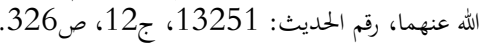

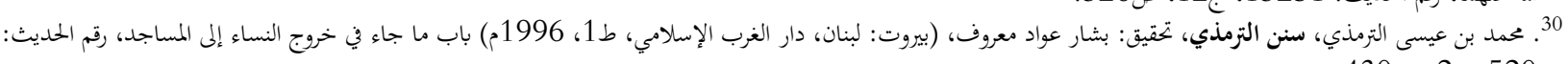

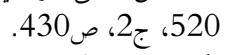

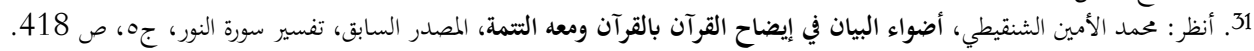

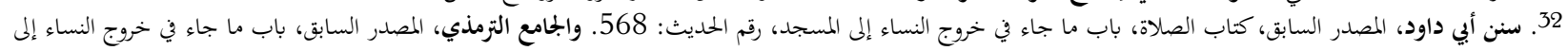
المساجد، رقم الحديث: 570.

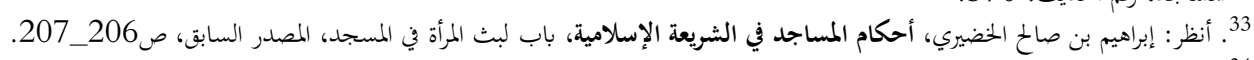

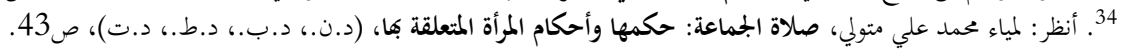


علدم النطيّب والتعطّر

التطيّب والتعطر هو زينة المرأة تزيّن به نفسها لأجل زوجها، وقد جاء عن أم أم المؤمنين حفصة رضي الله عنها

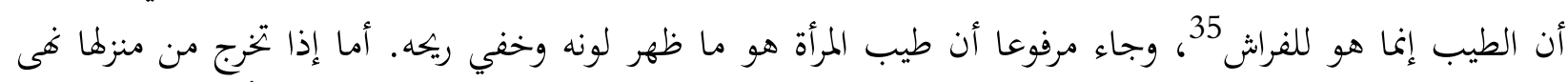

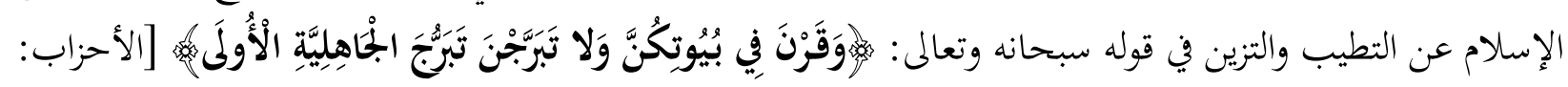

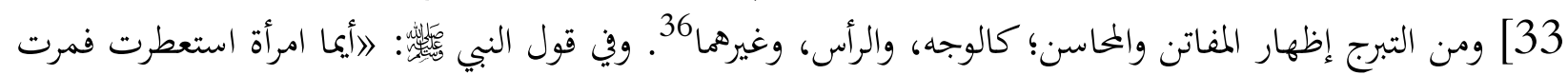

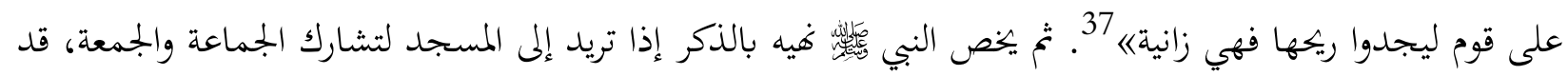

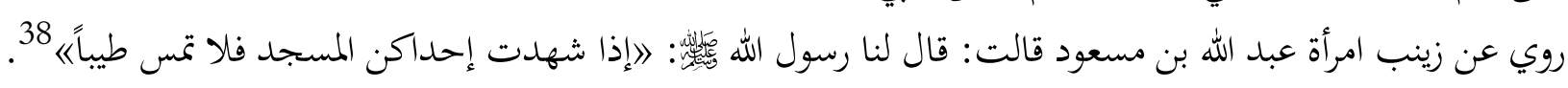

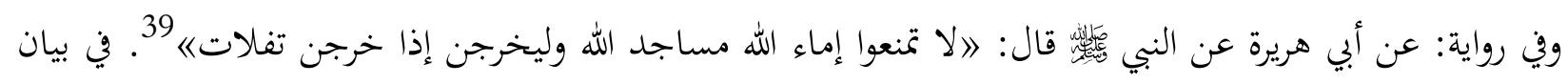

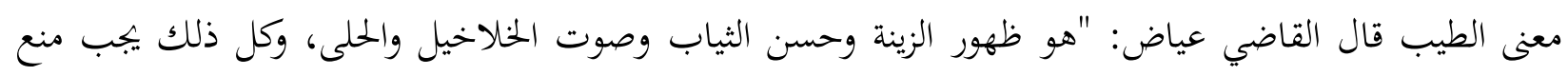

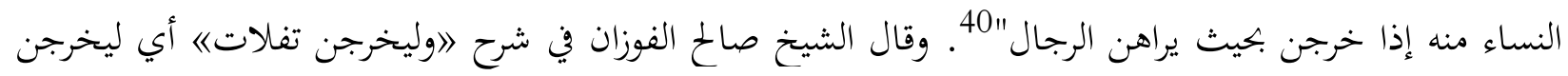

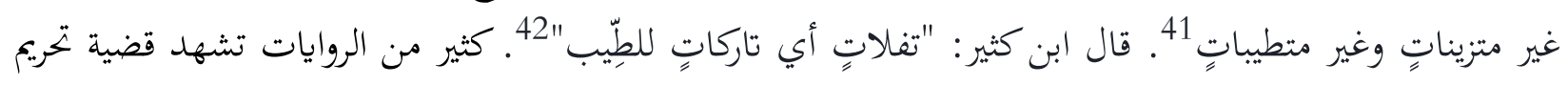

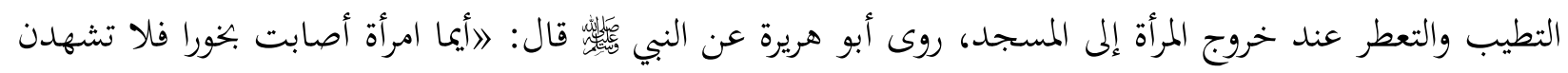

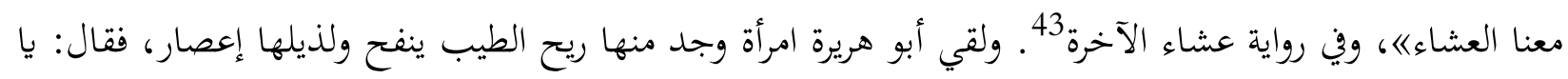

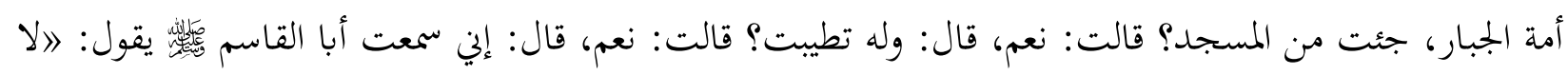

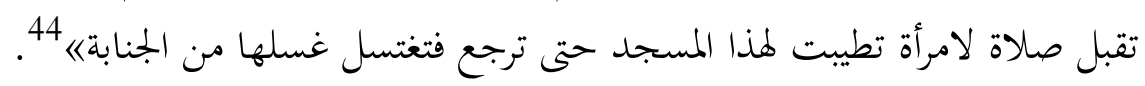

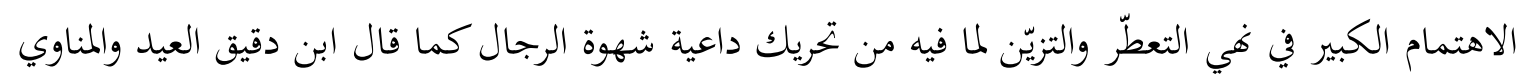

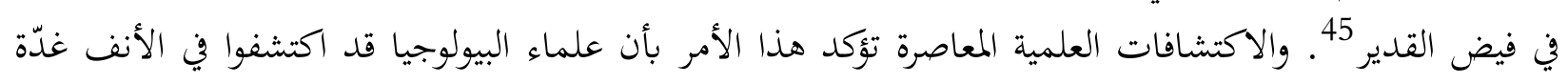

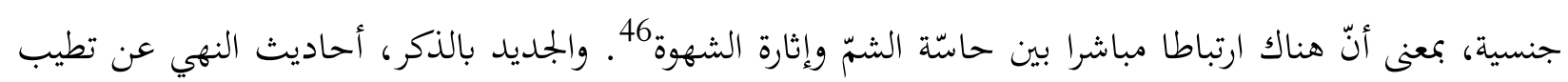

35 أنظر: أبو بكر عبد الرزاق بن همام الصنعاني، المصنف، (بيروت: المكتب الإسلامي، 11، 1391هـ-1972م)، ج4، ص373، رقم الحديث: 8113. ولفظ الحديث: "إنا الطيب للفراش". 36 أنظر : عبد العزيز بن عبد الله بن باز، حكم تطيب المرأة عند خروجها، (نشرت في البجلة العربية (بجلة شهرية) في العدد (168) لشهر صفر من عام 1412هـ، وفي بجلة الدعوة في

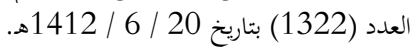

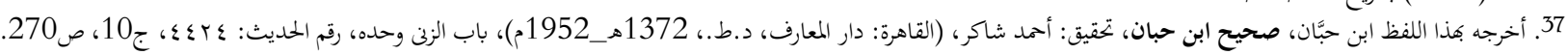

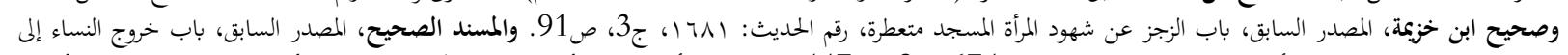

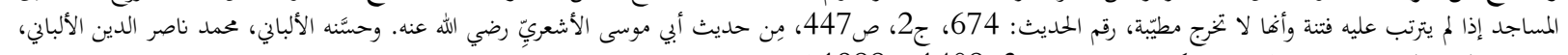

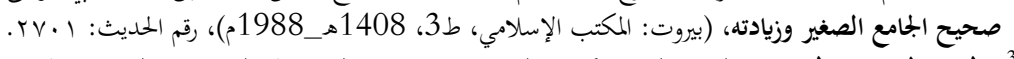

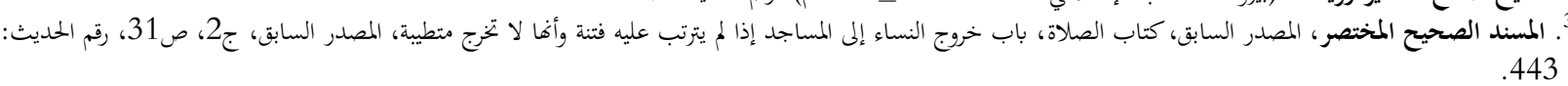

39 39 صحيح ابن خزيمة، المصدر السابق، باب الأمر بخروج النساء إلى المساجد تفلات، رقم الحديث: 1679، ج 3.

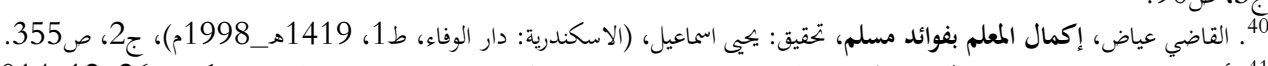

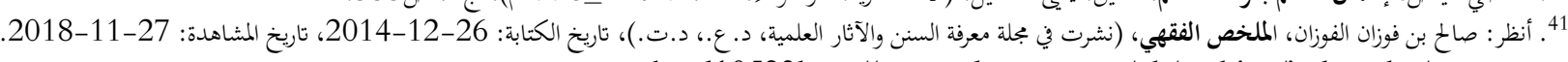

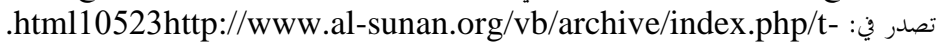

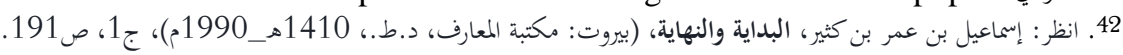

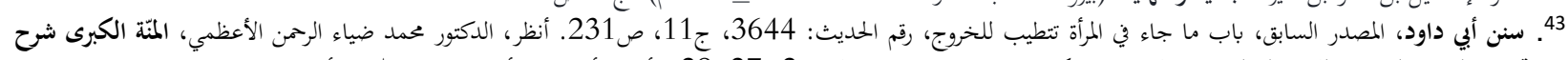

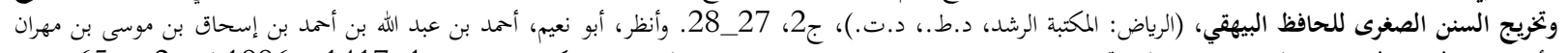

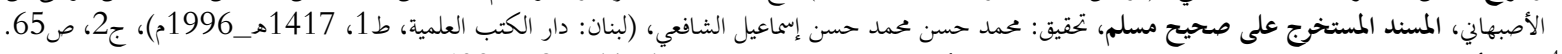

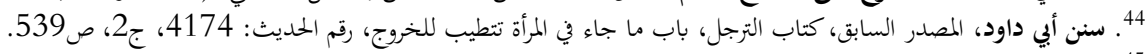

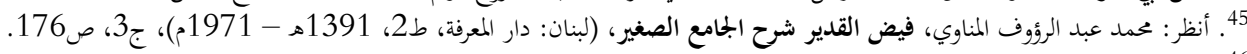

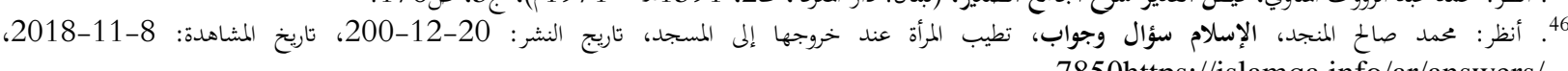
7850https://islamqa.info/ar/answers/ 
المرأة عند خروجها من بيتها لم تأت مطلقة، وإنما جاءت في سياق خروجها إلى مجامع الرجال أو المرور بهم، لما فيها من تحريك داعية الشهوة وإثارة الفتنة، ولذا جاء كثيرا منها مقيدا بخروجها إلى الصلاة. إذا كانت المرأة لن تمر بمجامع الرجال أو كان خروجها في جماعة النساء كقافلة النساء في السفر، فلا منع من التطيّب حينئذ، وهذا هو تخريج حديث عائشة رضي الله عنه في خروج أمهات المؤمنين متطيبات وهن محرمات، واحتج به الشافعي وأحمد 47.

الالتن/م بالحجاب

أن الحجاب والتستّر كان من عادة نساء الصحابة الذين هم خير القرون وأكرمها على الله عزّ وجل وأعلاها

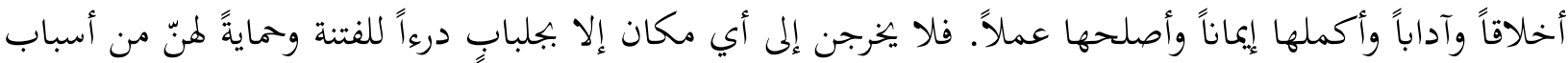

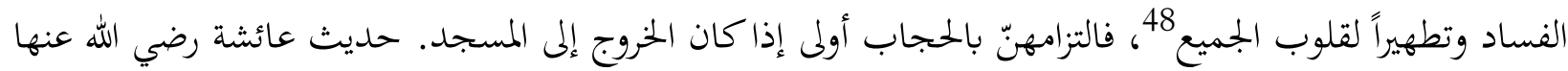

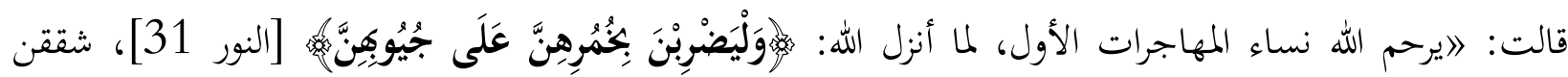

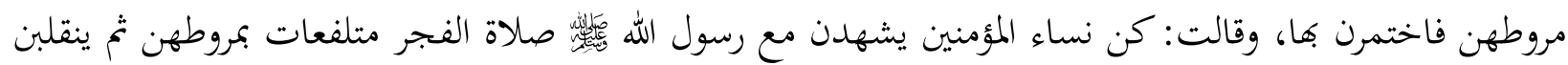

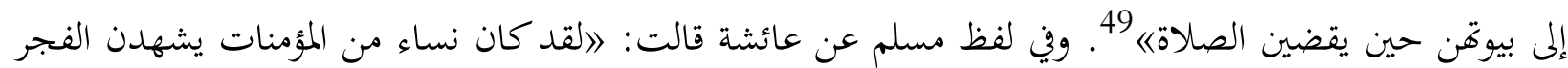

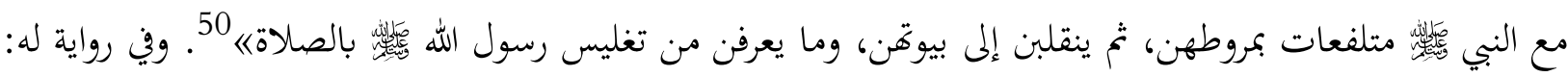

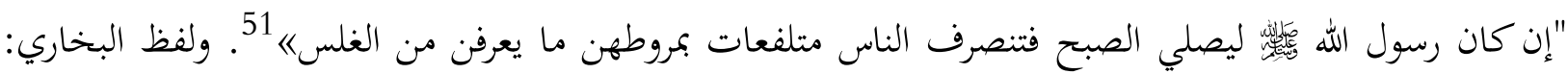

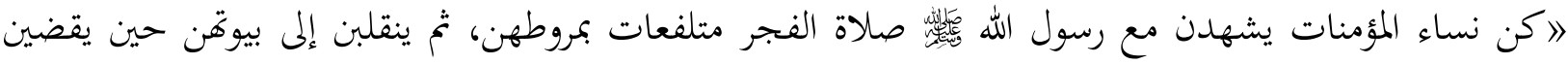
الصلاة لا يعرفن أحد من الغلسي"52. وفي رواية له: 》أنه عليه الصلاة والسلام كان يصلى الصبح بغلس، فينصرفن نساء المؤمنين لا يعرفن من الغلس، أو لا يعرفن بعضهن بعضاً/ 53 . يدل هذه الروايات على جواز إتيان النساء إلى ولى

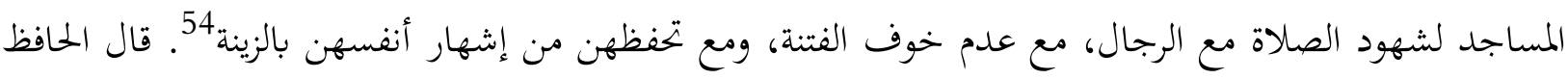
ابن حجر العسقلاني: "في الحديث فوائد: إحداهما: استحباب المبادرة بصلاة الصبح في أول وقت. والثانية: جواز خروج النساء إلى المساجد لشهود صلاة الليل. والثالثة: جواز خروج النساء للصالاة بالنهار من باب أولى، لأن الليل مظنة الريبة أكثر من النهار، ومحل ذلك إذا لم يخش عليهن أو بهنّ فتنة. والرابعة: استدل به بعضهم على جواز صله صلاة المرأة مختمرة الأنف والفم فكأنه جعل التلفع صفة لشهود الصلاة، وتعقبه عياض بأها إنما أخبرت عن هيئة الانصراف"

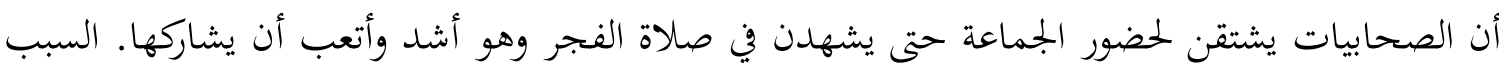

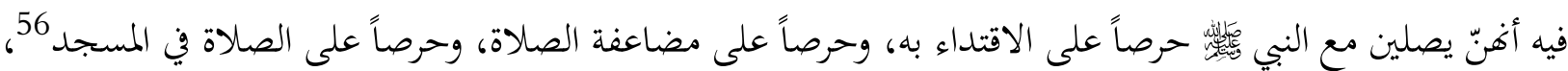

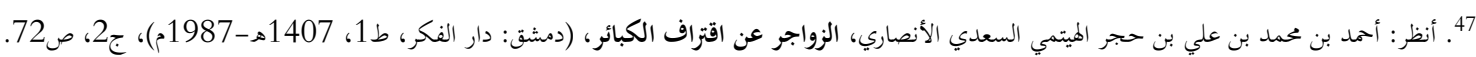

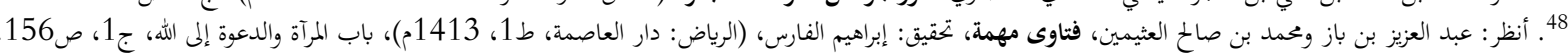

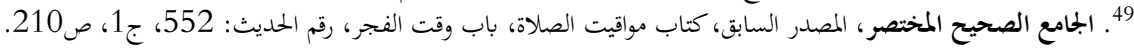
50. المسند الصحيح المختصر، المصدر السابق، كتاب المساجد ومواضع الصلاة، باب استحباب التبكير بالصبح في أول ولت وقتها وهو التغليس وبيان قدر القراءة فيها، رقم الحديث: 645،

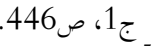

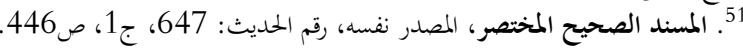

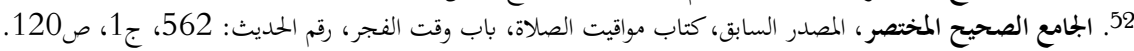

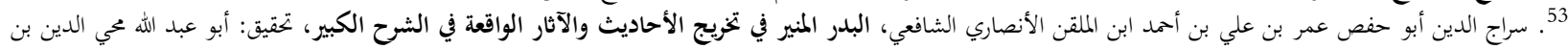

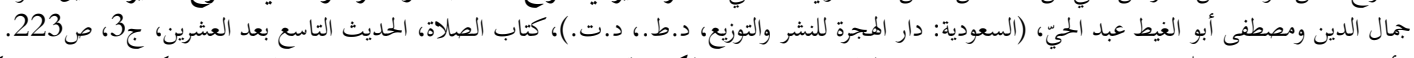

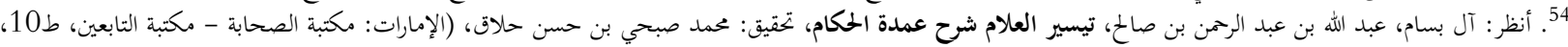

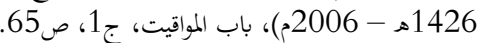

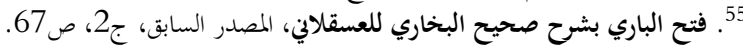

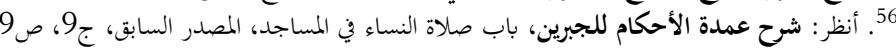


ولكن كُنَّ محتشمات في غاية التستر، كما قالت عائشة "متلفعات بمروطهنّ" أي مرتدية بردائها بحيث إفا تخرج متسترة في غاية التستر. الحقيقة أفنّ يغلقن كل أبوان الفتن ثم يخرجن لأداء الصالة، ولكن لا يغلقن أبواب المساجد ليخفين

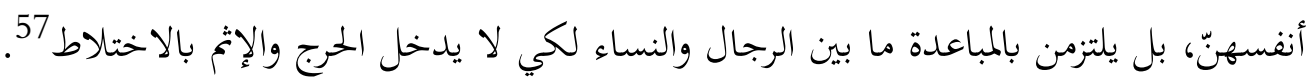

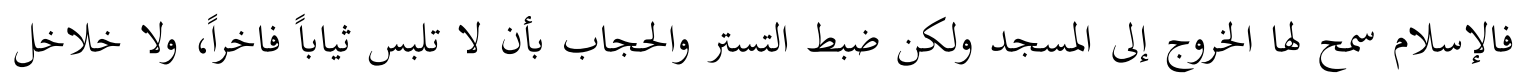

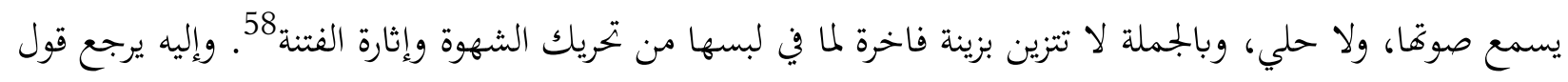

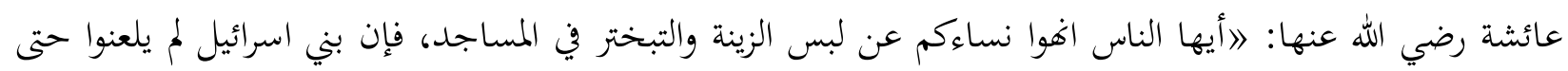
لبس نساؤهم الزينة، وتبختروا في المساجده

\section{المدي النبوي المتّبعة في الطريق إلى المسجد}

المشي بحافة الطريق المبوي المثبع

إن المرأة تحتاج إلى الخروج من البيت، إما للدراسة وإما للعمل. وكذلك تخرج لمشاركة الجماعة في المسجد كما

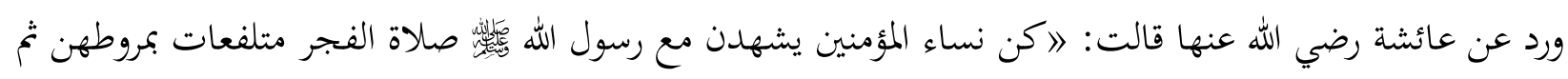
ينقلبن إلى بيوقن حين يقضين الصلاة)"60. ولو في الطريق يُوجد مجال الفتنة لكثرة الرجال فيه ما أغلق الإسلام باباً لحوائجها في خارج البيت. بل قنّ لما آداباً تلتزم حين تمشي في الطريق 61 فومن تلك الآداب ألا يمشين في وسط الطريق

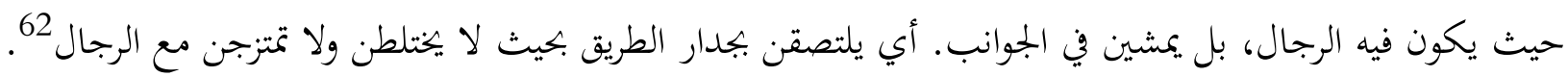

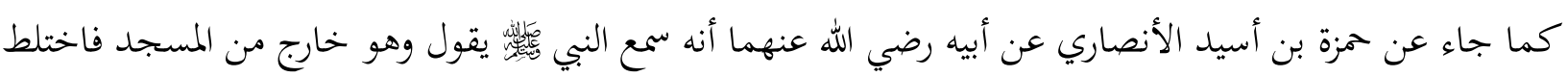

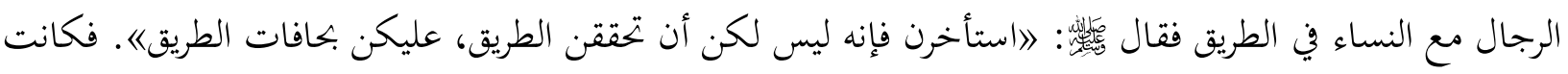
المرأة تلتصق بالجدار حتى إن ثوبها ليعلق بالجدار من لصوقها. حتى لا تختلط بالرجال وهي خارجة من المسجديد"

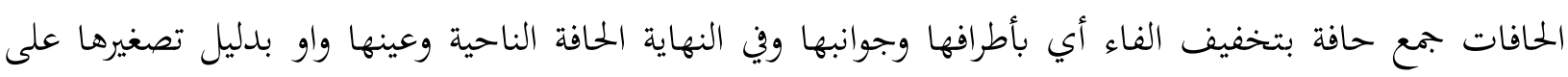
حويفة فكانت المرأة أي بعد ذلك الأمر تلصق بفتح الصاد أي تلزق بالجدار وتبالغ في لصوقها حتى إن بكسر الهمزة

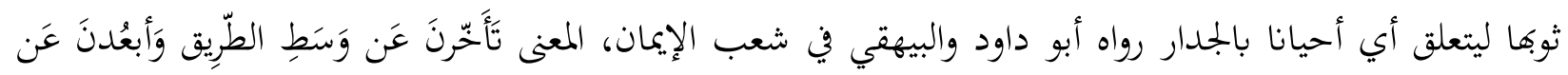

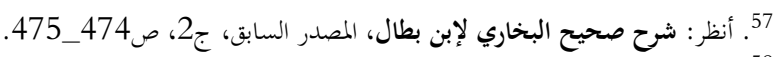

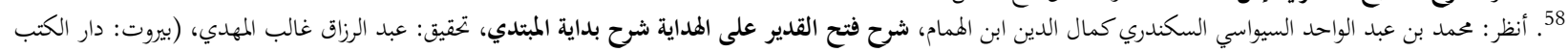

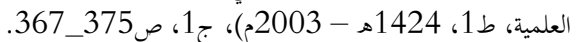

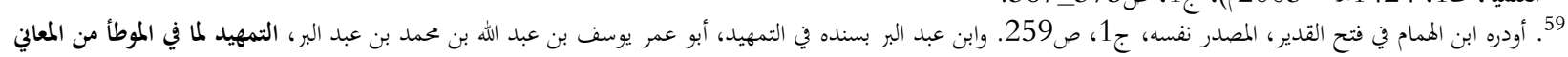

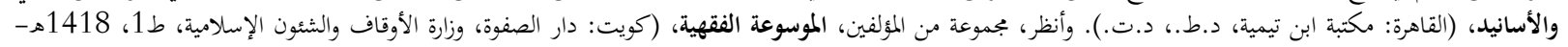

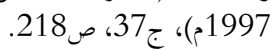

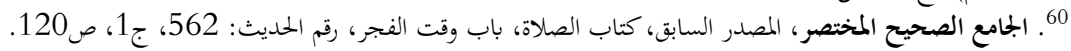

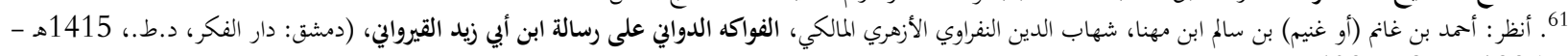

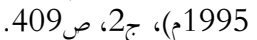

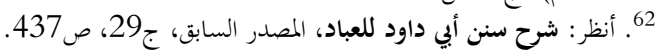

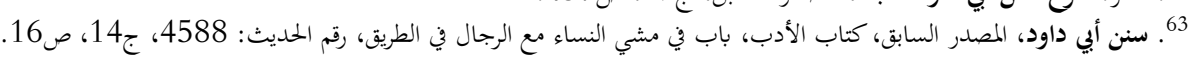




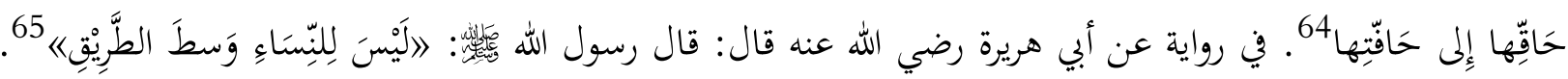
وشرح ابن حبان بأن مرادها الزجر عن شيء مضمر فيه، وهو مماسة النساء الرجال في المشي 66

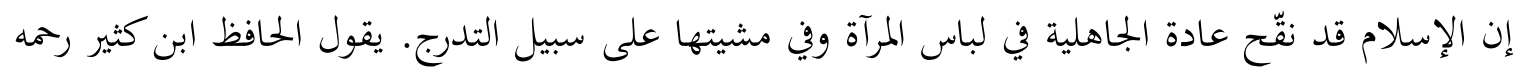
الله: "كانت المرأة في الجاهلية إذاكانت تمشي في الطريق وفي رجلها خلخال صامت لا يسمع صوته ضربت برجلها الأرض، فيعلم الرجال طنينه، فنهى الله المؤمنات عن مثل ذلك، وكذلك إذا كان شيء من زينتها مستورًا، فتحركت بحركة

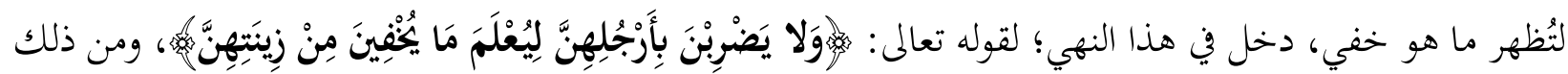

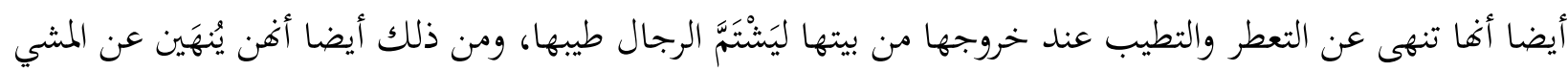

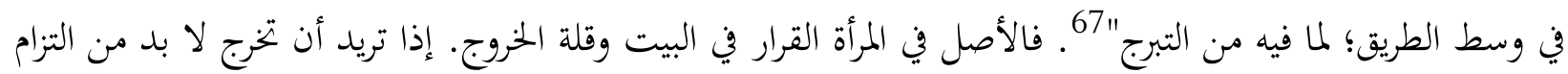
الجوانب في الطريق وفي كل أماكن العمل والتعليم، وفي جماعة المسجد أولى. وكذلك حرّمت الشريعة الإسلامية جميع الوسائط التي تجلب إلى الفتنة والاختلاط.

\section{المدي النبوي المتّبعة وقت دخول المستد}

الدخول من باب مخصوص الندوي المنبعه

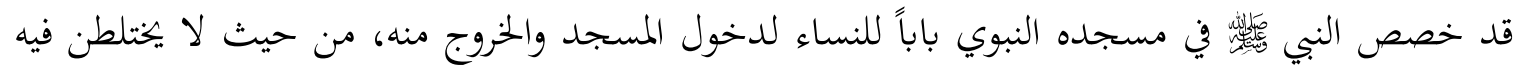

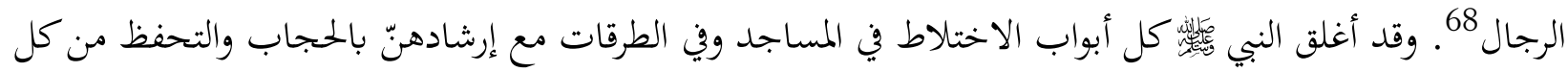
ما يثير الفتنة. في بداية الإسلام أحكام الحجاب والتستّر قد أنزل بالتدرج، فالرجال والنساء كانوا يدخلن المسجد من

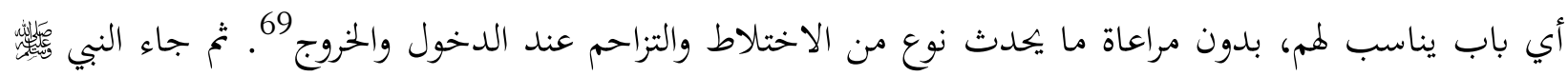
بإرشاد جديد فقال: 》الو تركنا هذا الباب للنساء《"70. وهذا الحلديث له روايات كثيرة، قال الإمام أبو داؤد: أصح الرواية ما رواه إسماعيل بن إبراهيم عن أيوب عن نافع قال قال عمر ثم متن الحديث نفسه 71.

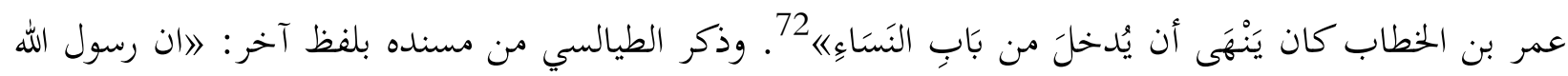

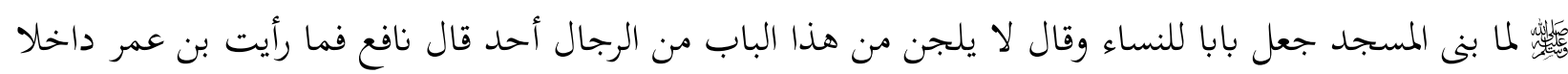

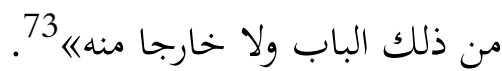

قال عبد المحسن العباد في بيان المفهوم من هذه الروايات بأن المرأة تحضر الجماعة بما فيه أجر عظيم، أما الأجر

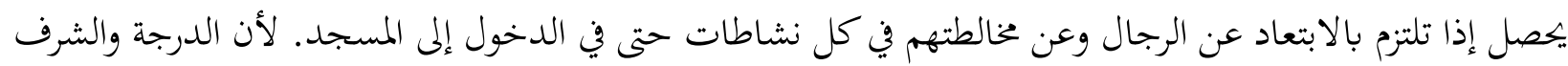

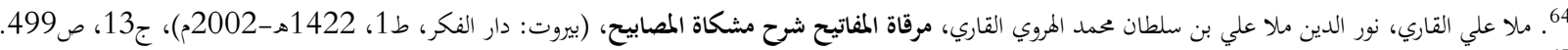

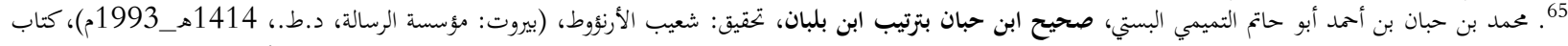

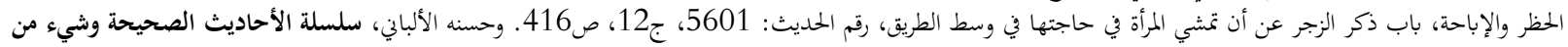

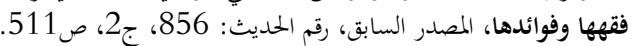

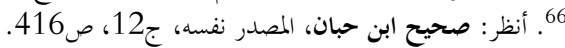

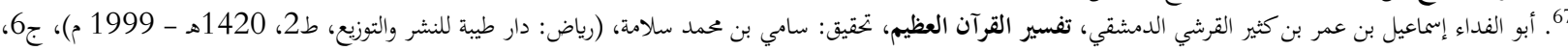

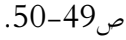

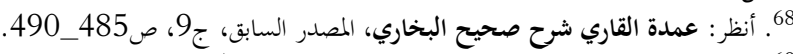

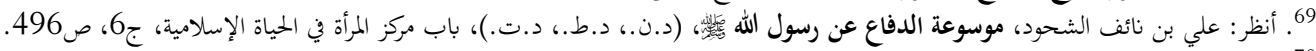

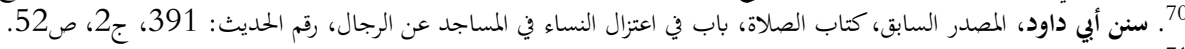

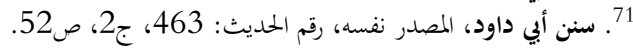

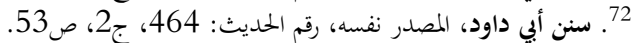

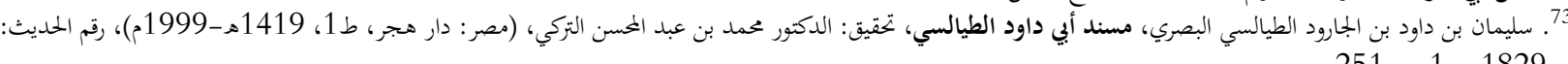




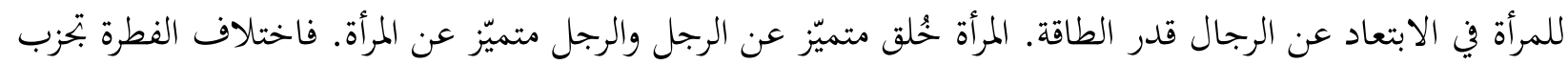

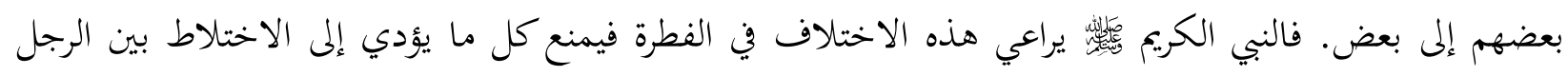

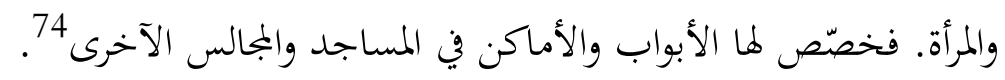

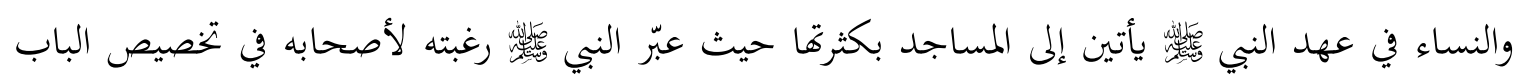

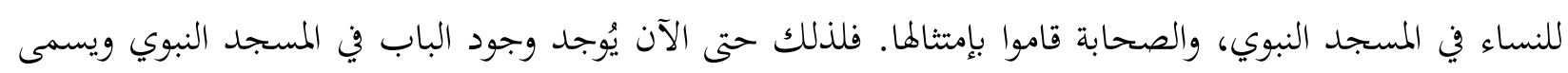

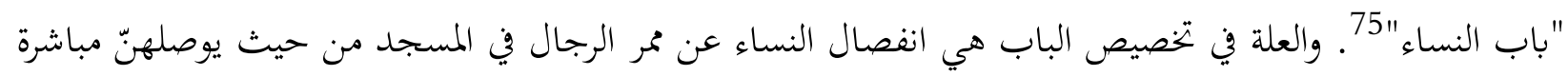

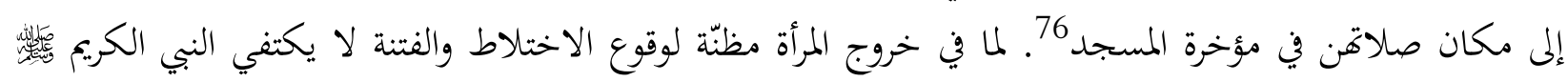

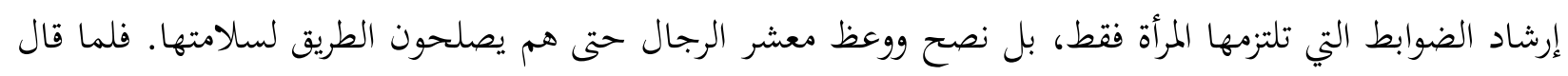

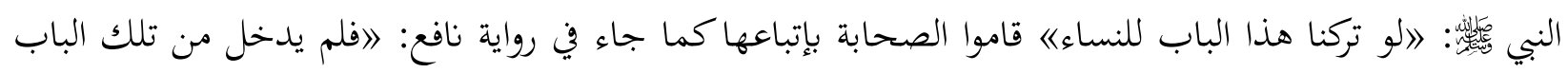

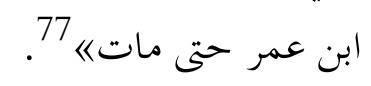

المدي النبوي المتّبعة في داخل المسجد تصغيف المرأة

في صفوف المرأة روايات كثيرة أخرجها ابن أبي شيبة ومسلم وأبو داود والترمذي وابن ماجة وغيرهم. والأشهر

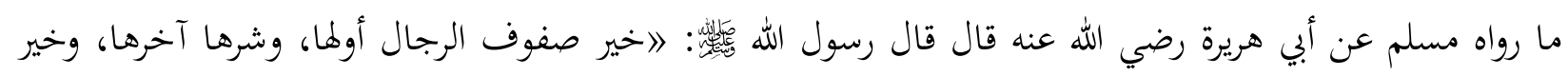

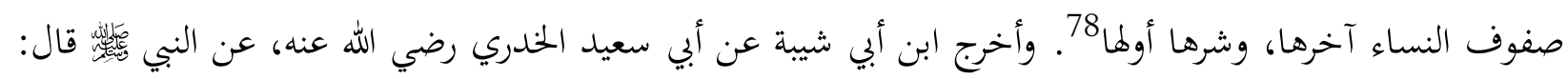

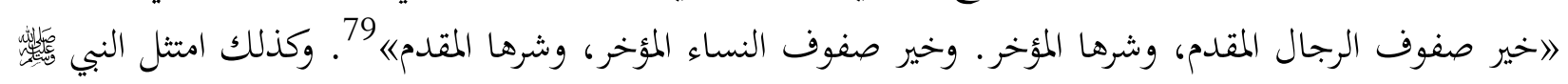

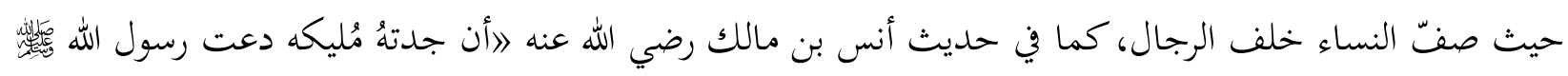

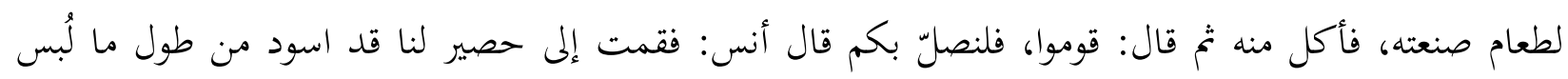

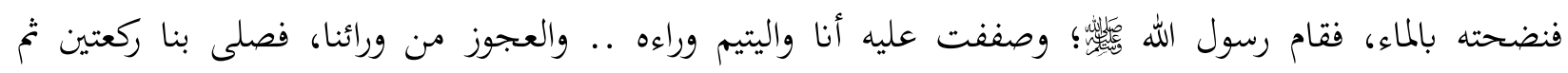

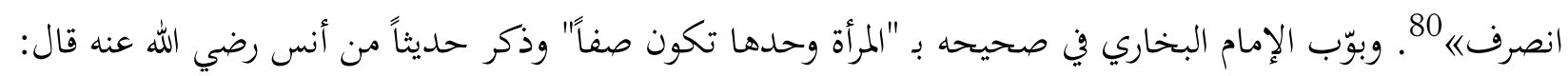

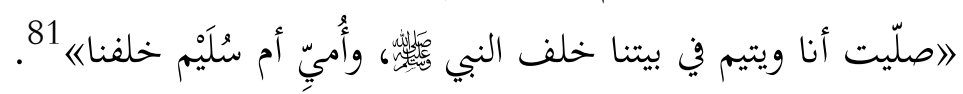

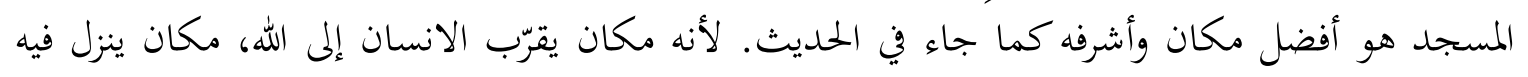

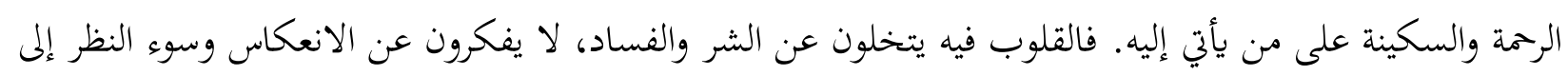

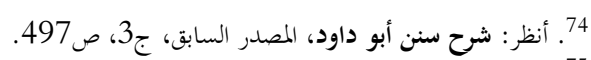

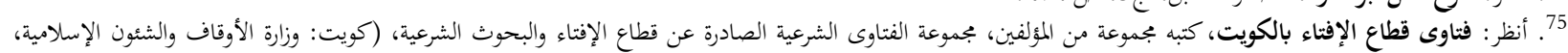

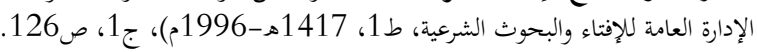

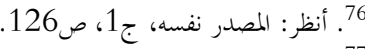

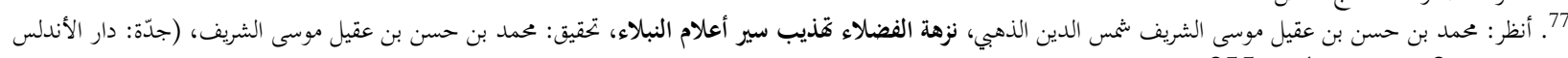

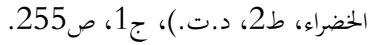

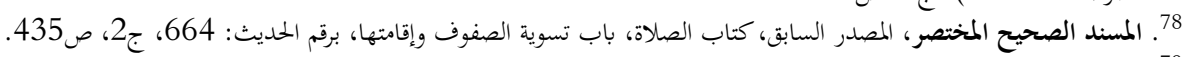

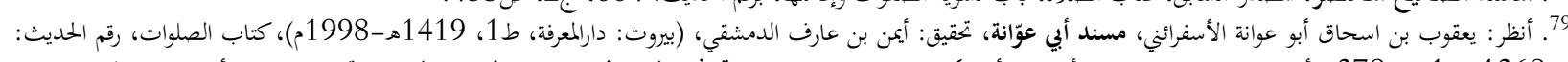

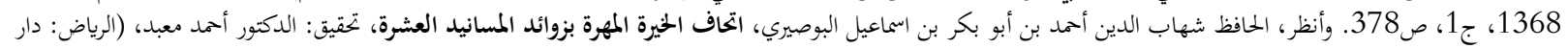

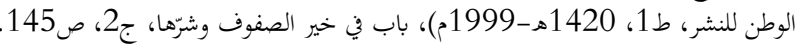

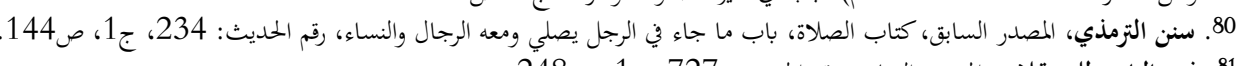

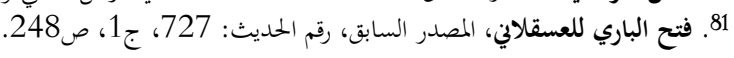




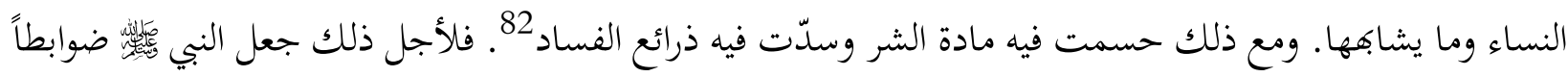

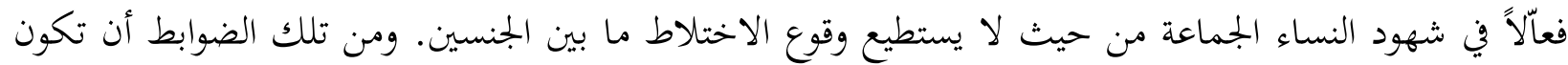

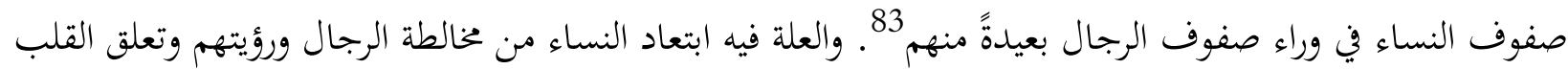

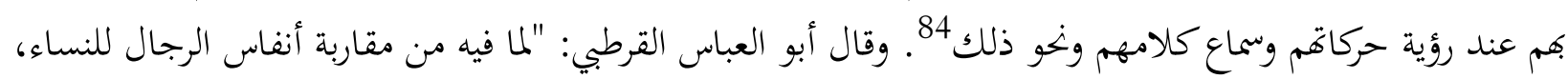

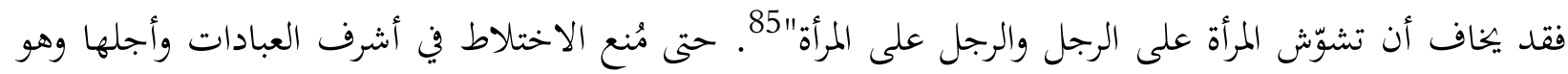

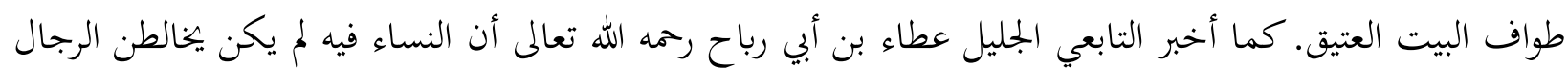

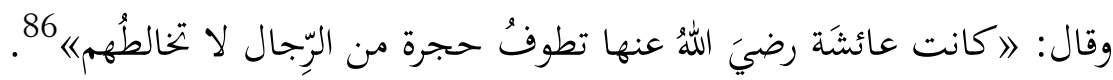

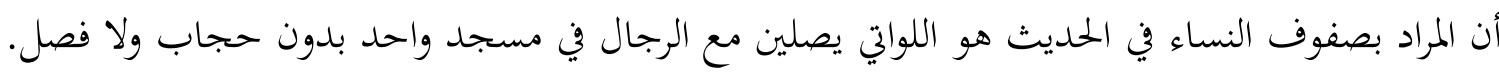

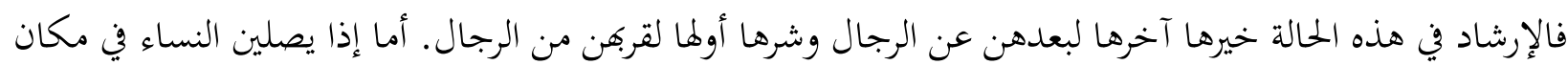

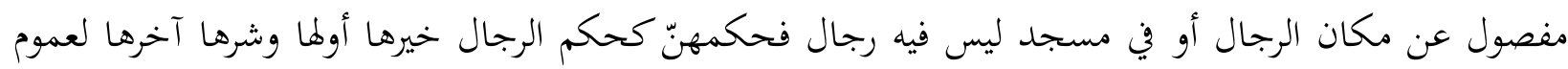

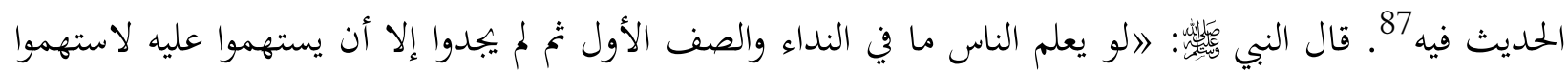

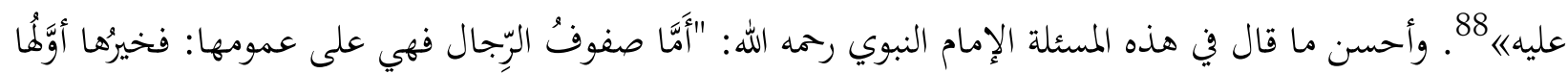

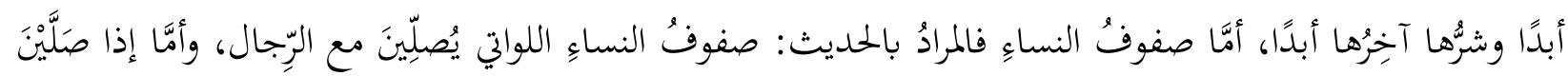

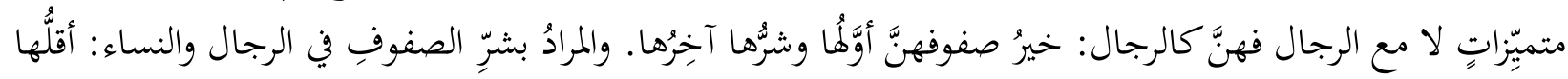

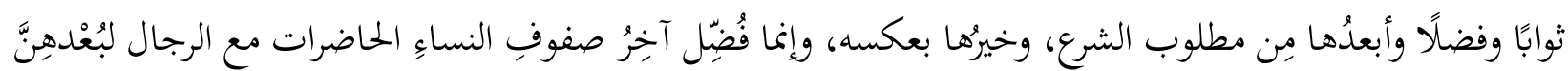

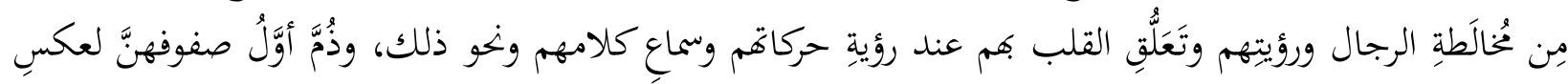

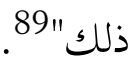

والنتيجة من هذه النقاش بأن المرأة قد شهدت الجماعة في عهد النبي البّأ مع سلامة واطمئنان. لأن القوانين

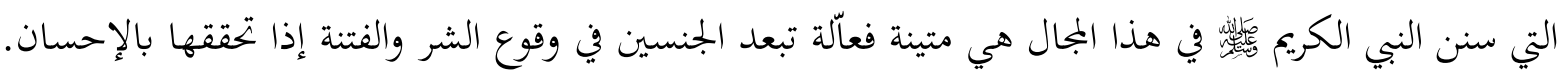

غض البصر

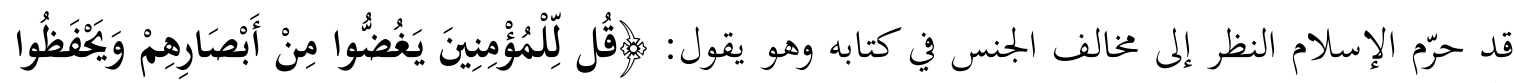

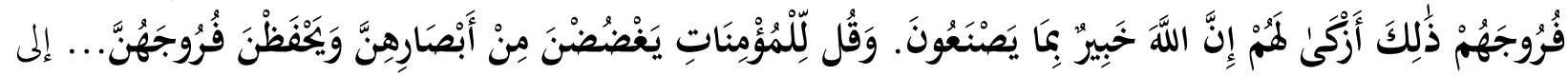

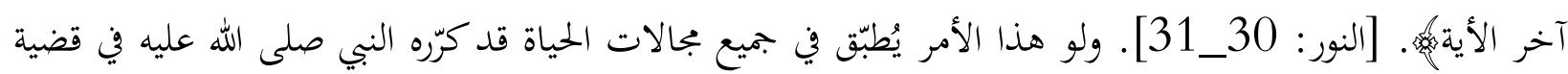

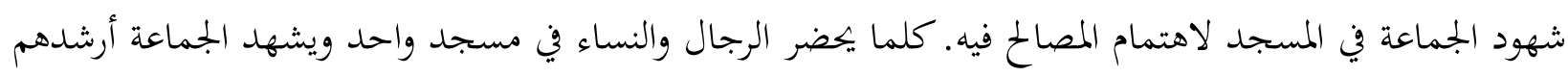

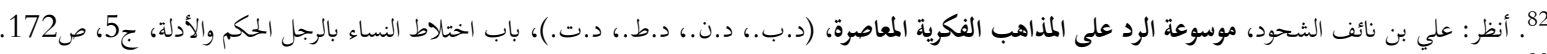

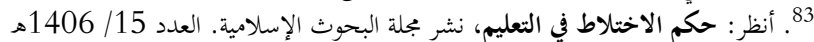

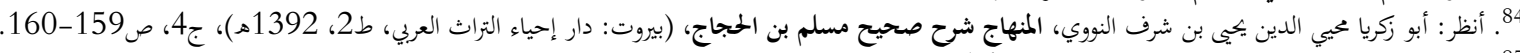

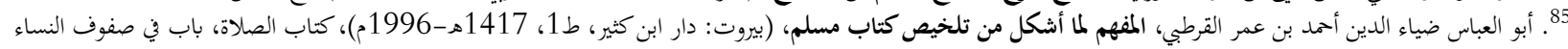

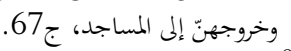

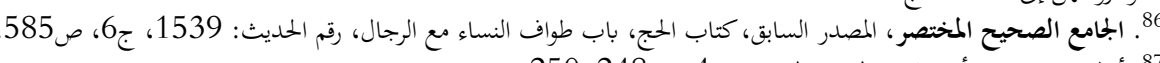

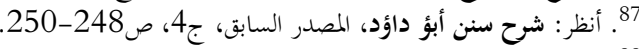

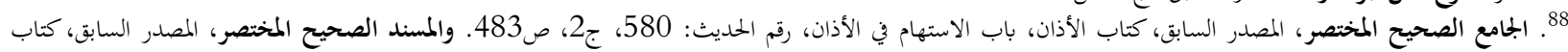

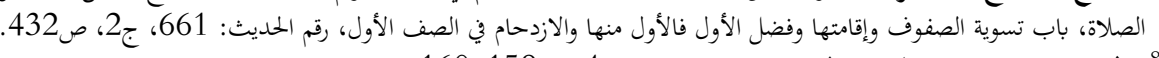

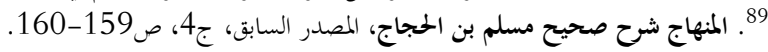


النبي أبل إلى مسئلة غض البصر بعضهم من بعض. أي لا تلتفت إليهم النساء ولا يخون الرجال أعينهم بالنظر إليهنّ.

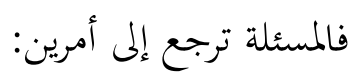
الأمر الأول: نظر المرأة إلى الرجل أريل

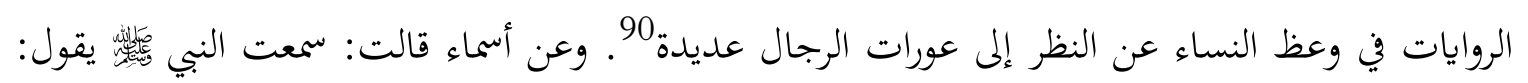

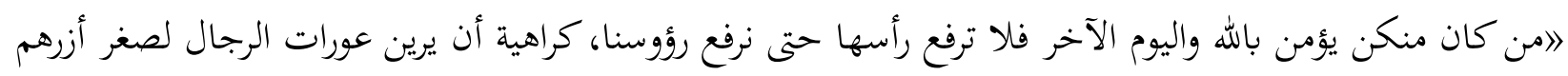

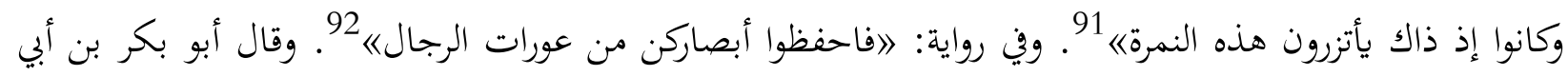

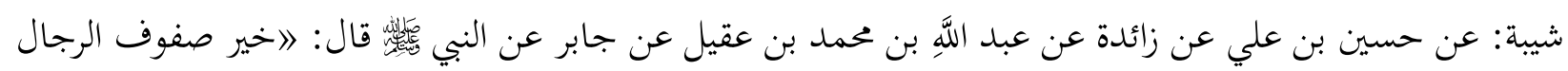

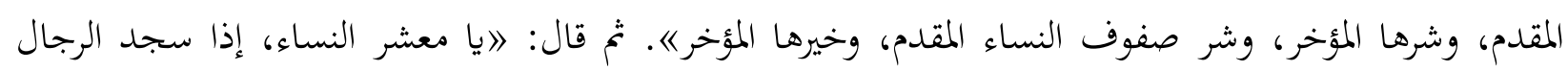

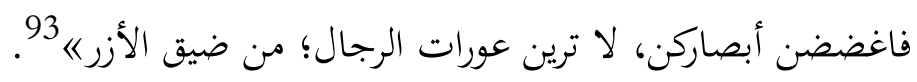

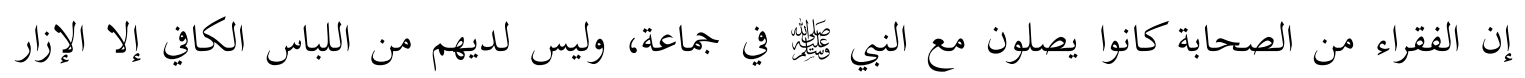

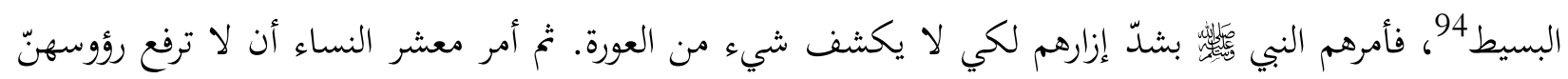

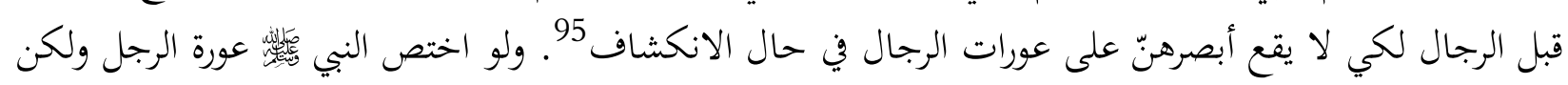

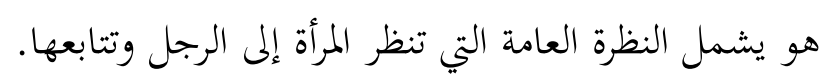
الأمر الثاني: نظر الرجل إلى المرأة

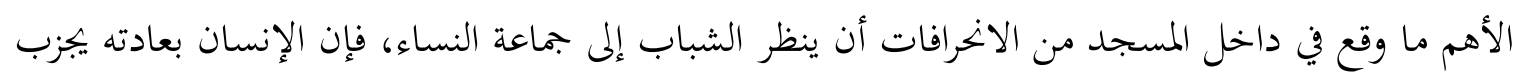

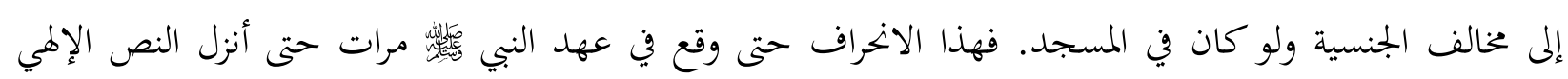

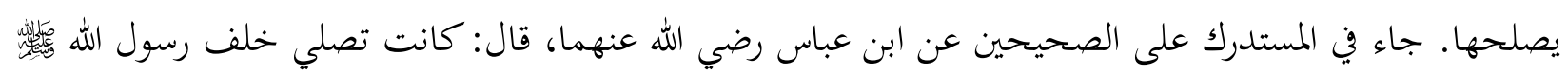

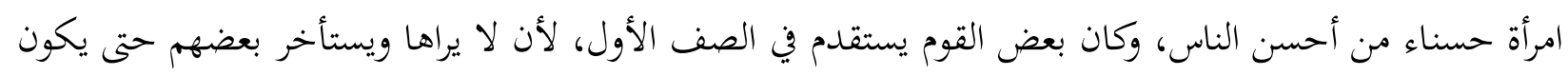

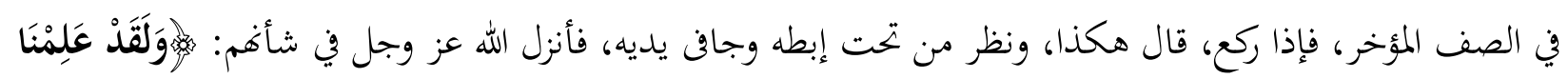

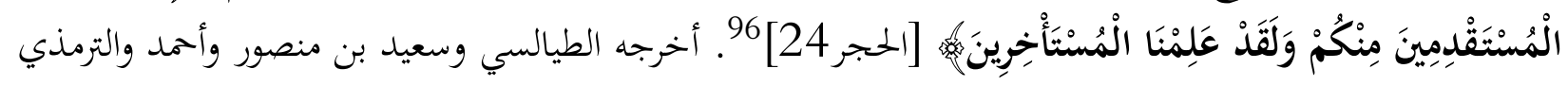

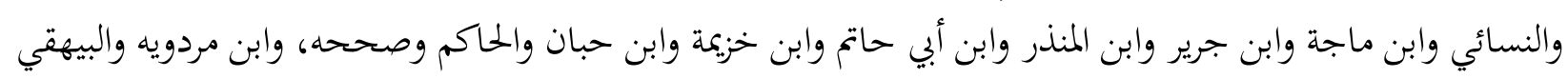

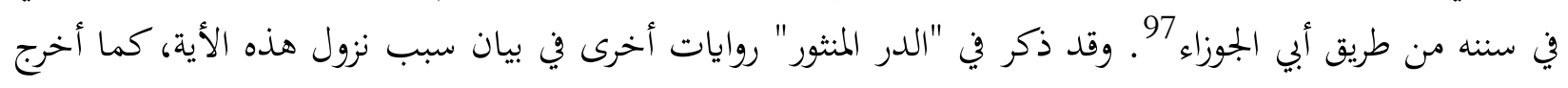

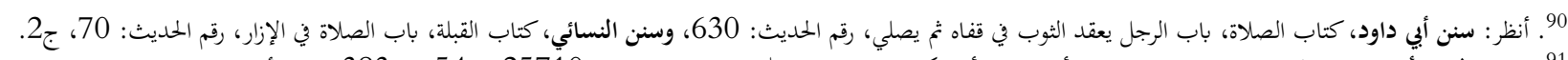

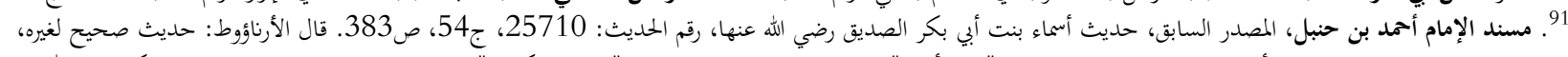

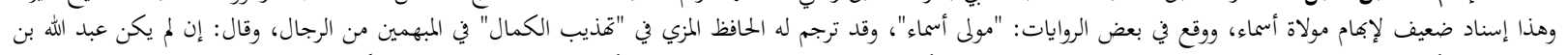

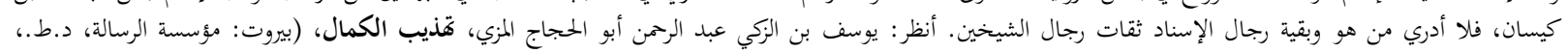

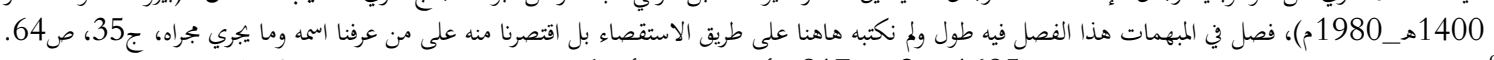

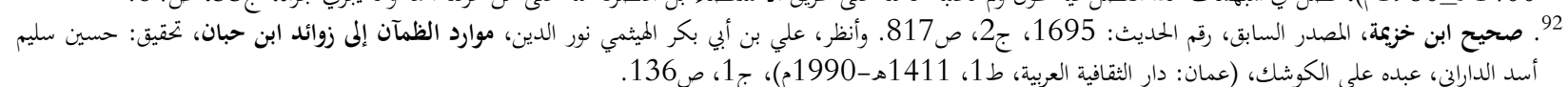

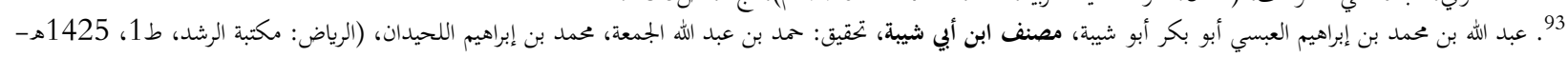

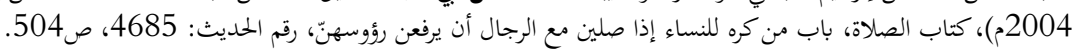

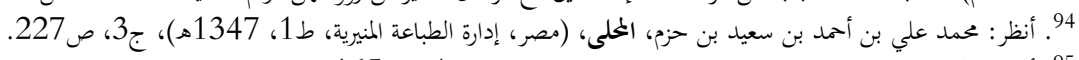

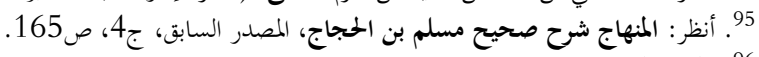

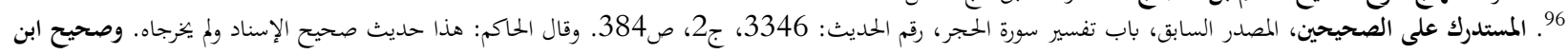

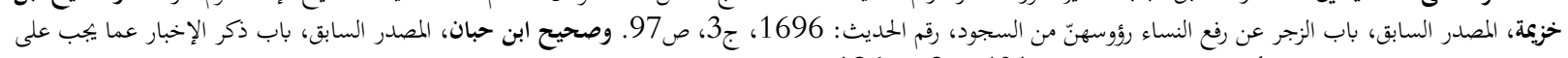

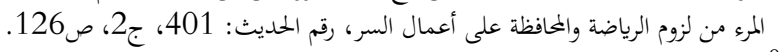

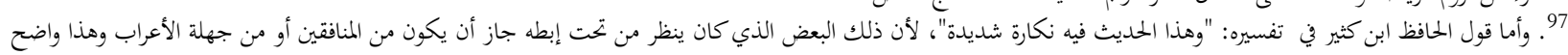

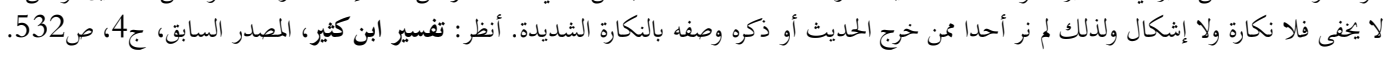




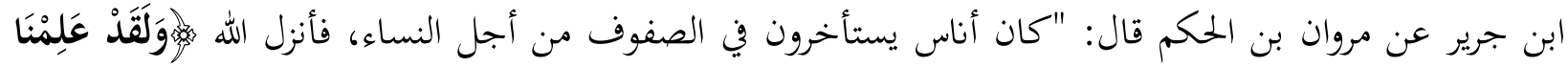

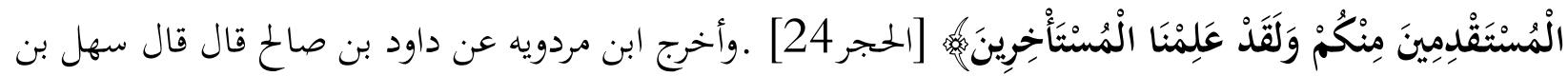

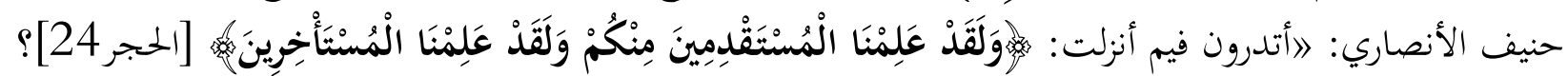
قلت: في سبيل الله. قال: لا، ولكنها في صفوف الصلاة/ 98 يُرئ من هذه الروايات السابقة أن مجتمع المدينة فيه وقع

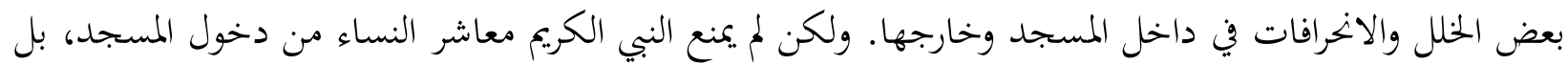
تعامل مع هذه الاخراف بالوعظ والتذكرة برقابة الله تعالى على عباده 99.

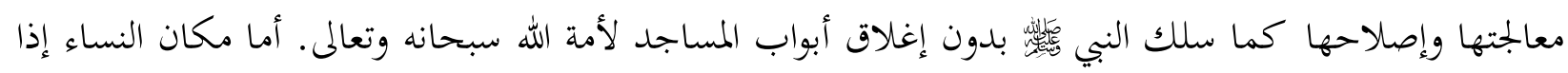
كان مفصول من مكان الرجال فلا إشكال فيه ولا خوف لوقوع فتنة النظر والاختلاط.

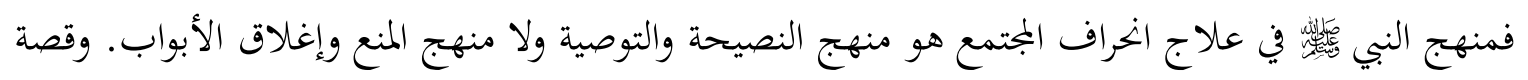
فضل بن عباس يدل على هذا100. أخرج هذا الحديث أحمد والنسائي وغيرها عن ابن عباس رضي الله عنه: اأن امرأة

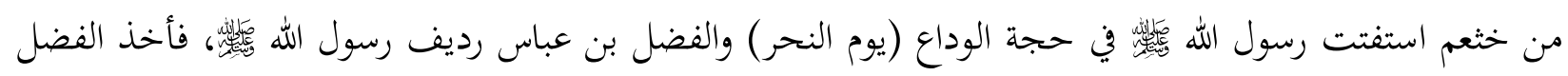

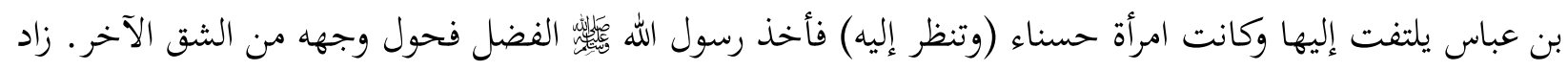

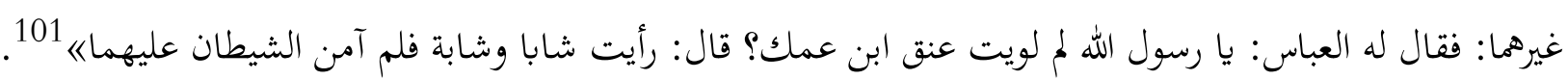

التصغيق للنساء

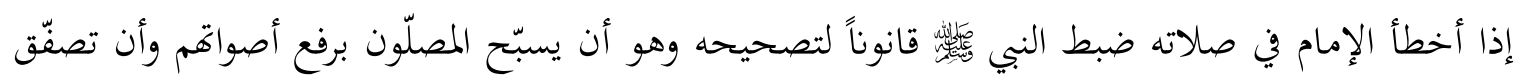

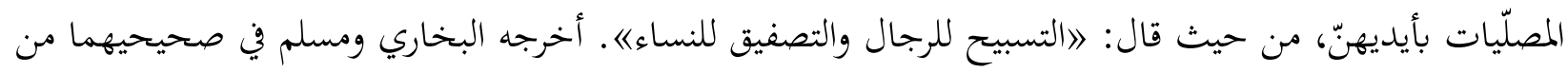
حديث أبي هريرة رضي الله عنه102. وكرّر الإمام بخاري نفس الحديث عن سهل بن سعد رضي الله عند عنه

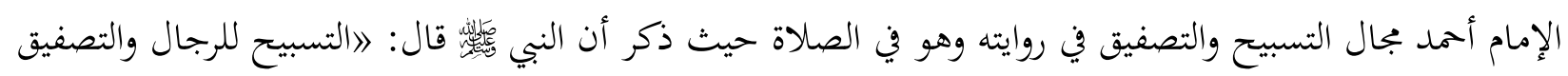
للنساء في الصلاة/104 . والسبب لتخصيص التصفيق للنساء لما فيه الحجاب في سماع أصواتن للرجال، لأن صوت

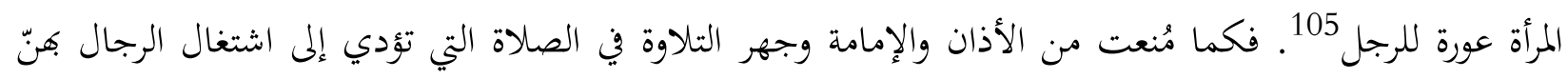

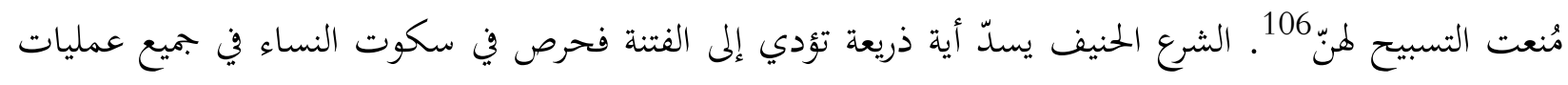

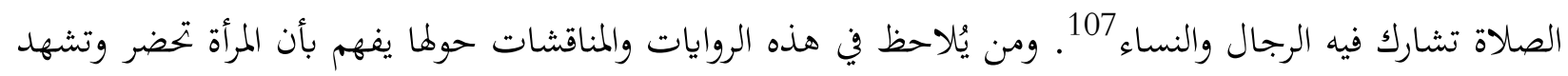
صلاة الجماعة وتساهم في إقامتها وفي إصلاحها.

98 9. جلال الدين عبد الرحمن بن أبي بكر أبو الفضل السيوطي، الدر المنثور في التفسير بالمأثور، تحقيق: عبد الله بن عبد المحسن التركي، (القاهرة: مركز هجر للبحوث والدراسات العربية

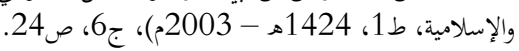

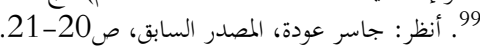

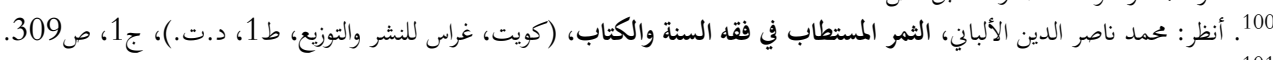
101 . وهذا سند صحيح على شرط الشيخين.

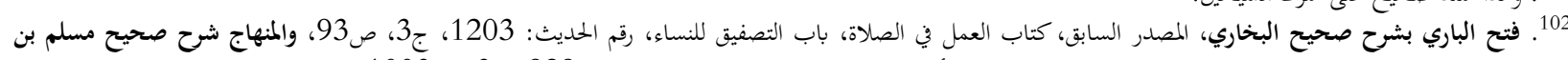

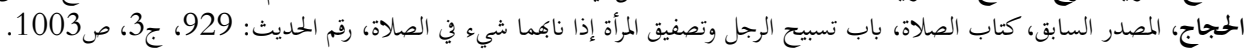

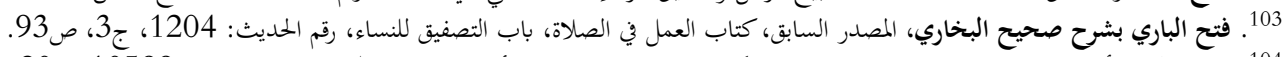

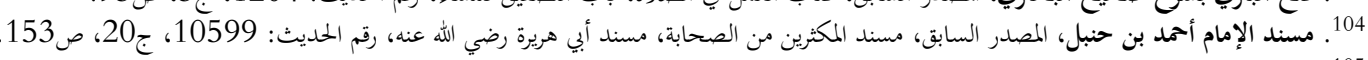

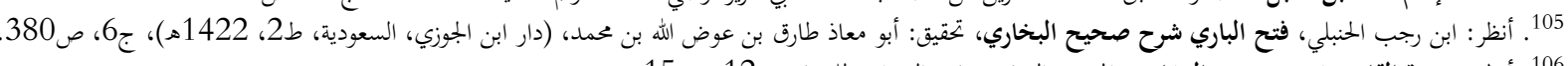

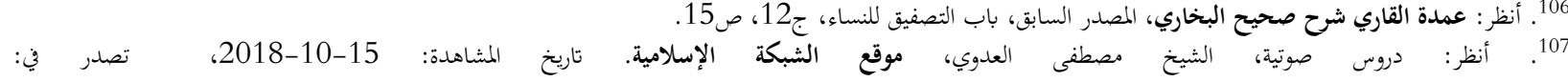
773http://audio.islamweb.net/audio/index.php?page=lecview\&sid= 
استماع التلاوة في الصلاة

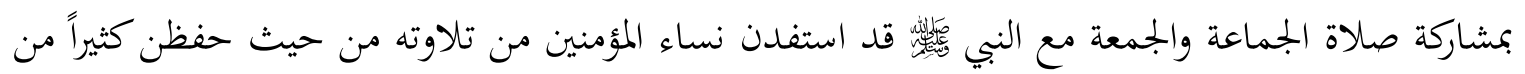

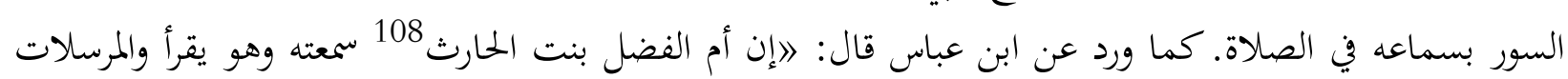

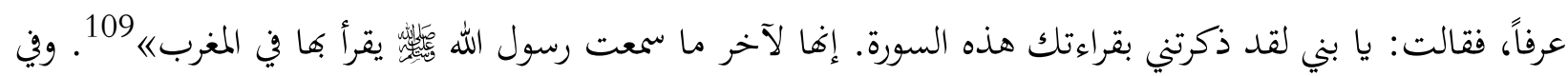

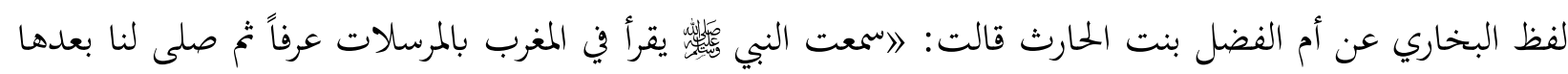
حتى قبضه الله|110. ورواية أم هشام بنت حارثة بن النعمان عن سماع التلاوة في صلاة الجمعة حيث قالت: لاما

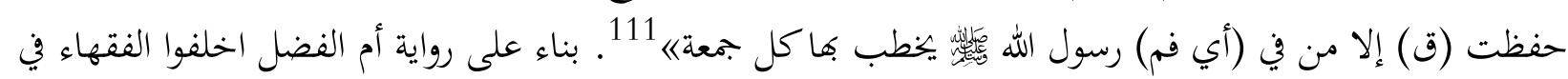
استحباب التلاوة لصلاة المغرب أهي المفصل أو الطوال أو الطوال المفصل؟ هذا المكان لا يناسب لبيانه هنا. بل التركيز هو قدوم المرأة في المسجد وشهود الجماعة ثم سماع التلاوة ثم التحفيظ والاستفادة منها.

بكاء الصبي

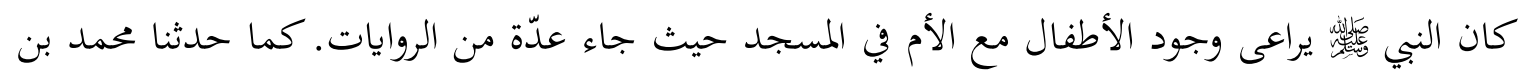
مسكين قال حدثنا بشر قال أخبرنا الأوزاعي قال حدثني يهيى بن أبي كثير عن عبد الله بن أبي قتادة الأنصاري عن ابيه قال قال رسول الله: اإني لأقوم في الصلاة وأريد أن أطول فيها، فأسمع بكاء الصبي، فأتجوز في صلاتي كراهية أن أشق بن

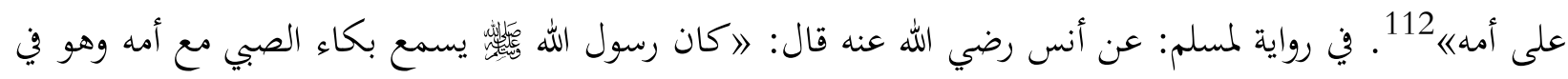

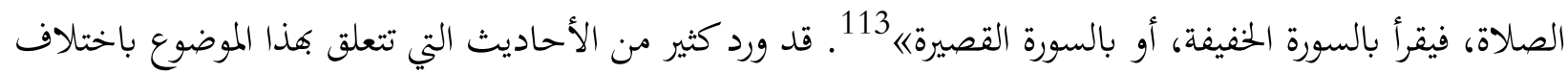

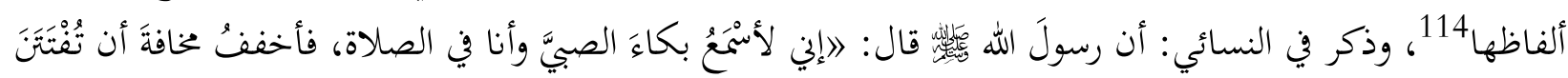
أُ أُّهُه 115

ذكر الإمام النووي في بيان دلالة هذا الحديث حيث قال: "وفيه دليل على الرفق بالمأمومين وسائر الاتباع

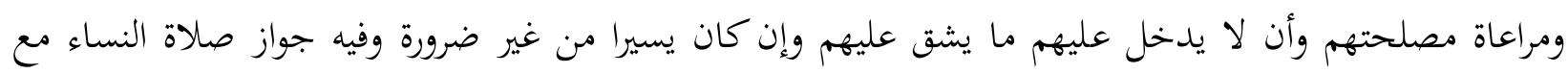

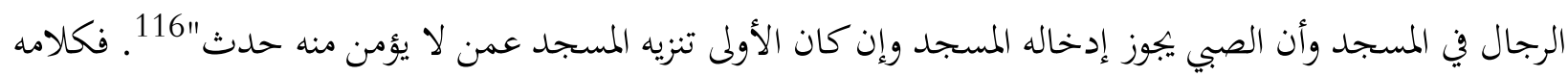

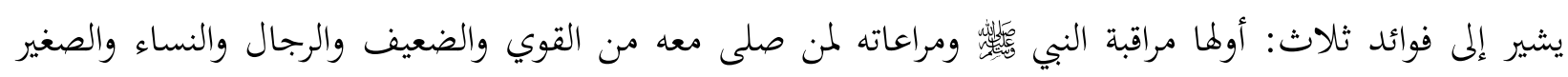

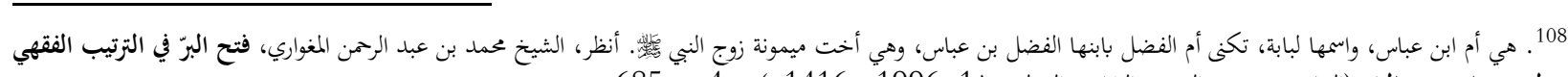

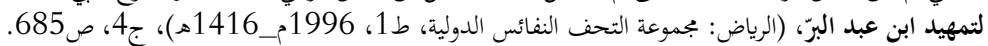

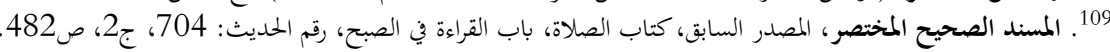

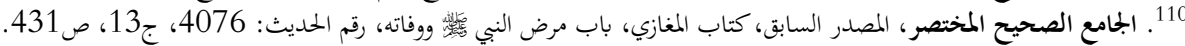

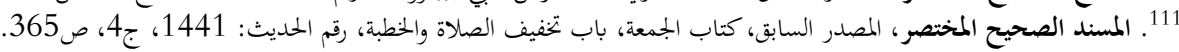

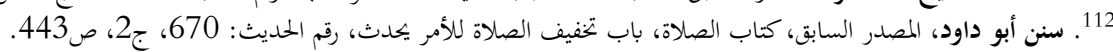

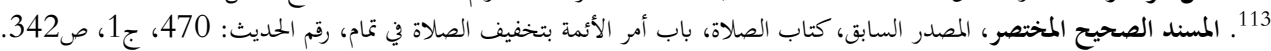

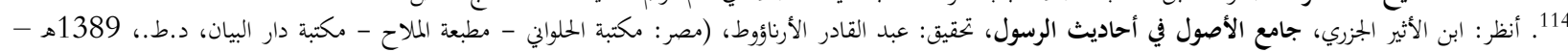

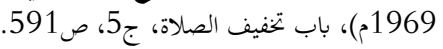

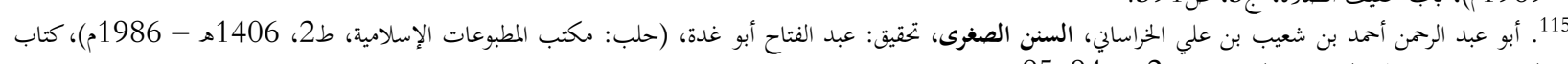

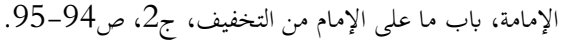
116. المنهاج شرح صحيح مسلم بن الحجاج، باب اعتدال أركان الصلاة وتغنيفها في تمام، ج4، ص187.
} 
والكبير 117 حتى قام بتخفيف الصلاة لما فيه مصالحهم ودفع كلما يشقّ عليهم 118 . والثاني أن الحديث يثبت حضور

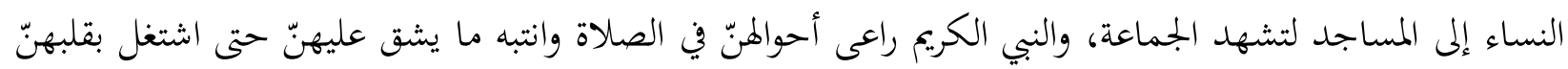

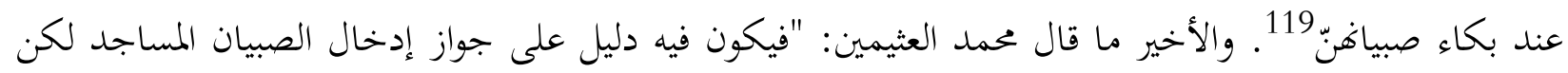
بشرط أن لا يحصل منهم أذية لا على المسجد ولا على المصلين فإن كان يخشى منهم أذية على المسجد كتلويثه بالبول والنجاسة فإفم يمنعون وكذلك إذا كان يخشى منهم التشويش على الناس بالصراخ والركض والجلبة فإفم يمنعون أيضا أما إذا لم يكن منهم بأس" "120. هذا من عادات بعض المجتمعات أن يمنع الأطفال من المساجد، حتى يزجرهم إذا يلعب الذي يؤدي إلى بعدهم

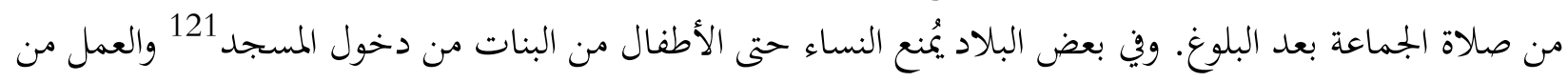

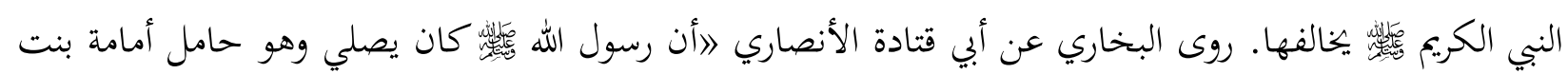

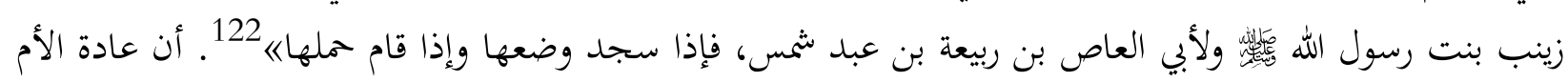

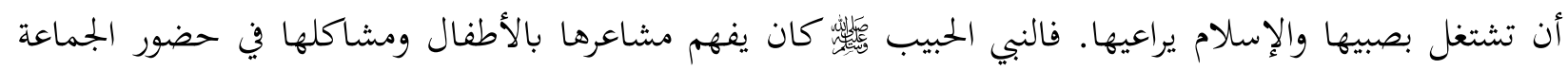

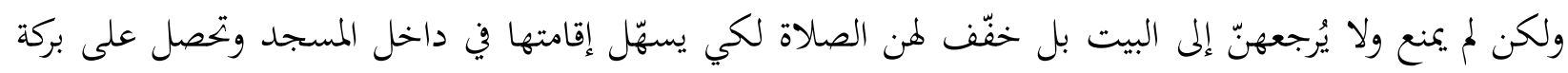

\section{الهدي النبوي المتّبعة وقت الانصراف \\ انصرافهنّ قبل الرجال}

بعد قضاء الصلاة في المسجد تغادر المرأة سريعاً قبل الرجال، والهدي النبوي يثبته. في رواية عن أم سلمة، زوج

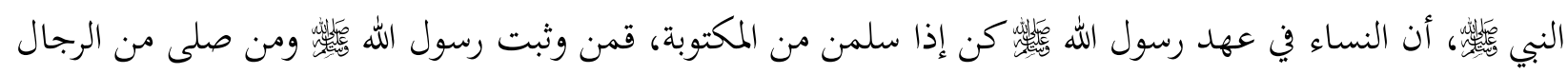

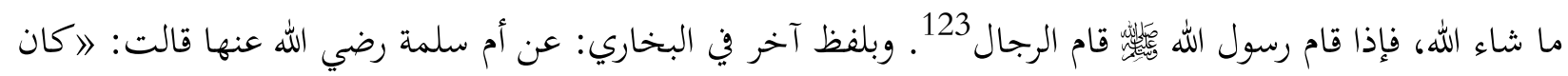

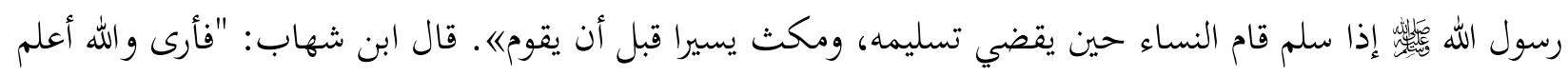

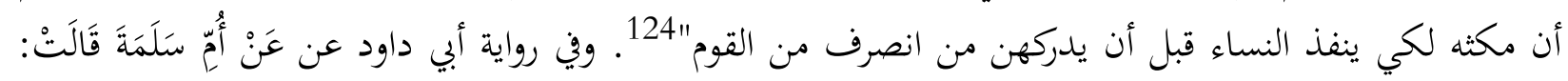

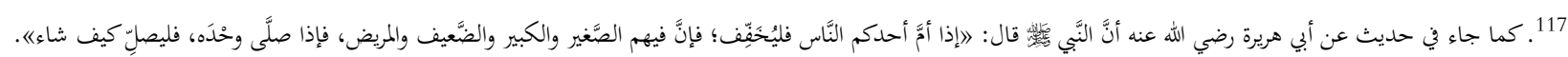

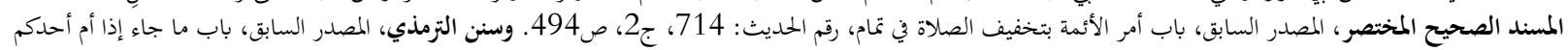

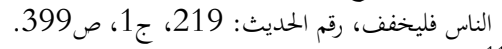

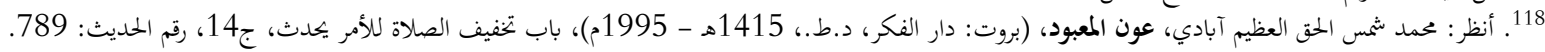

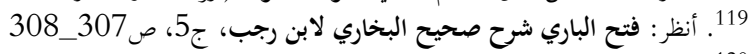

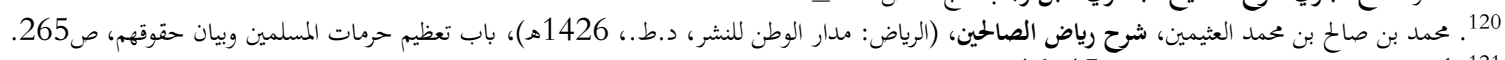

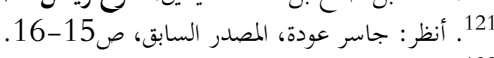

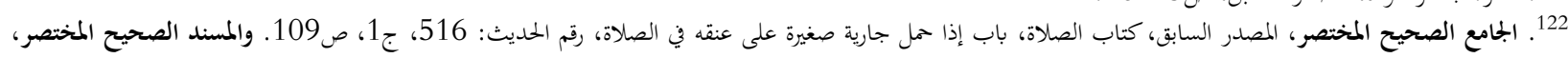

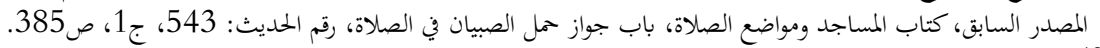

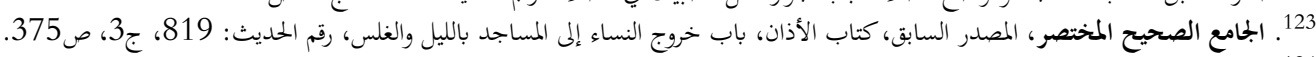

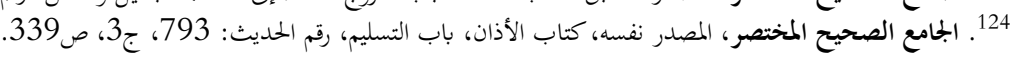


ا كَانَ رَسُولُ اللَّهِ

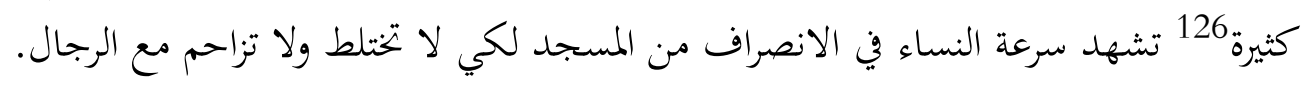

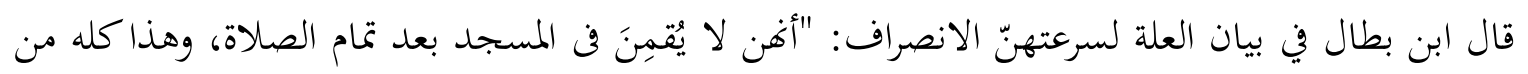

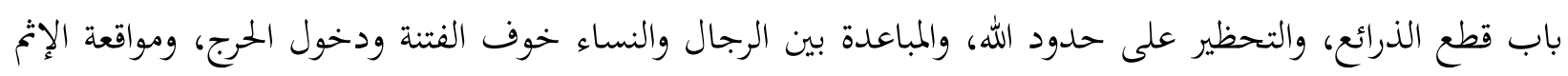

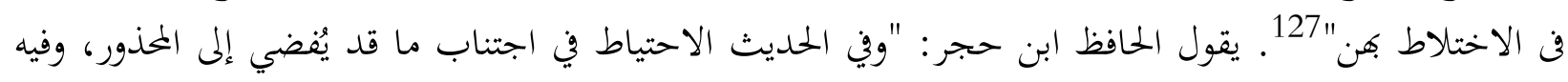

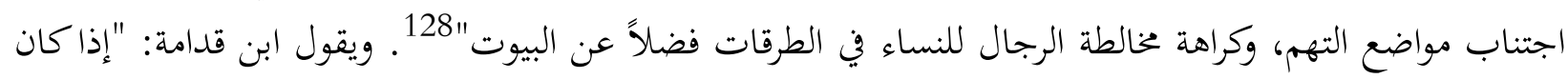

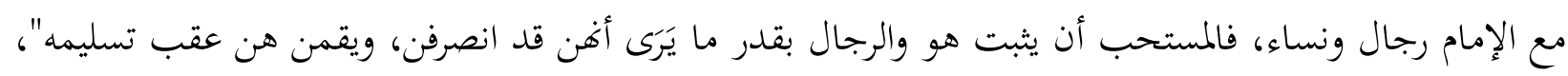

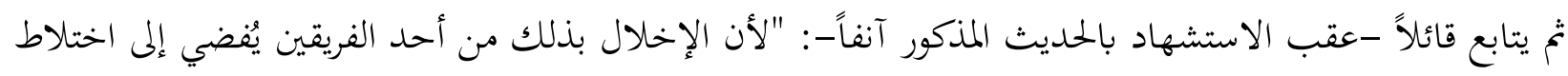

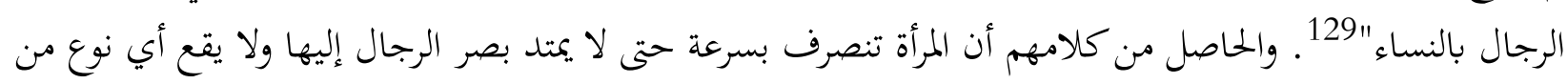
الاختلاط والانخراف فيه 130

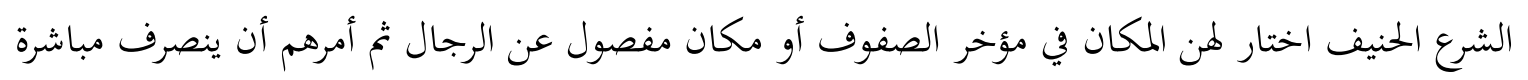

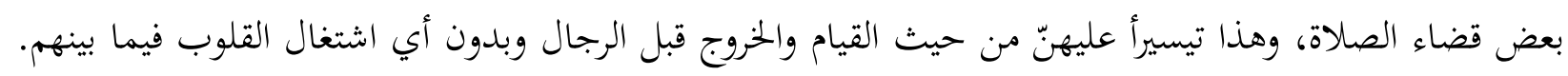

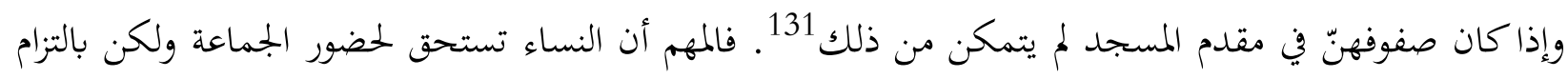

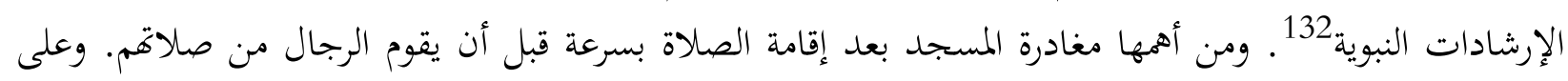

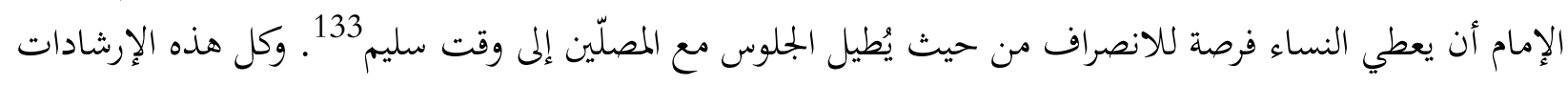

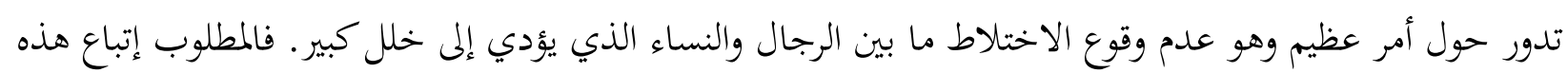

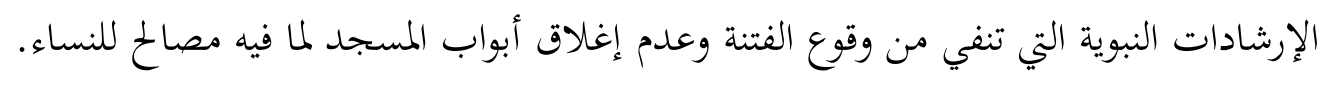

خاتمة

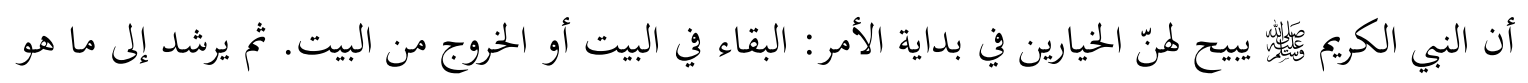

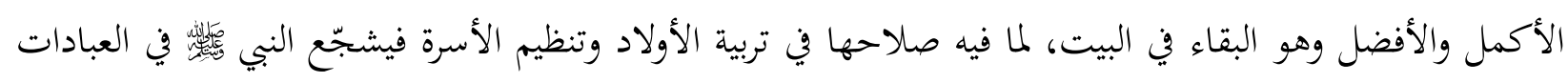

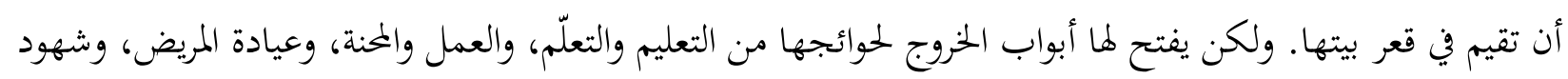

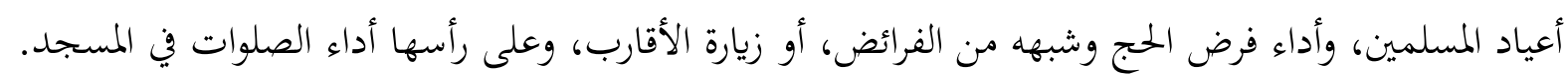

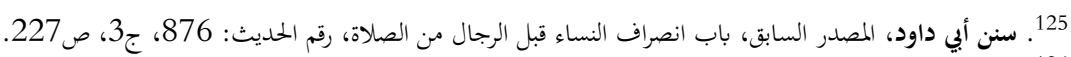

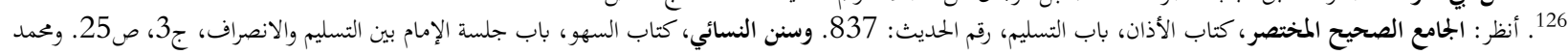

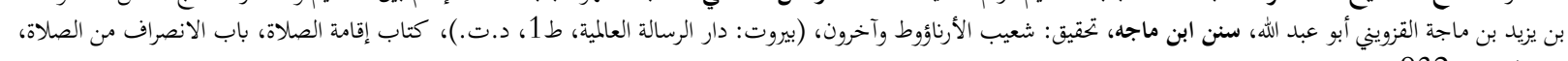
رقم الحديث: 932.

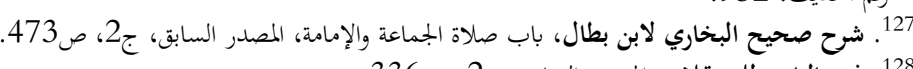

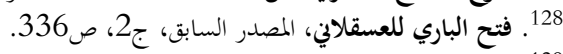

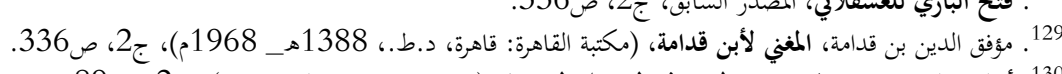

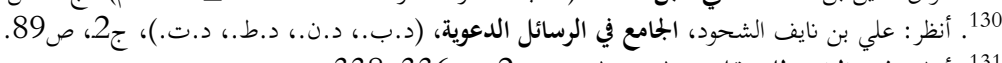

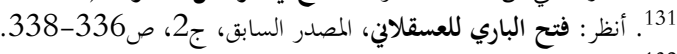

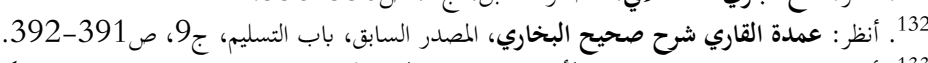

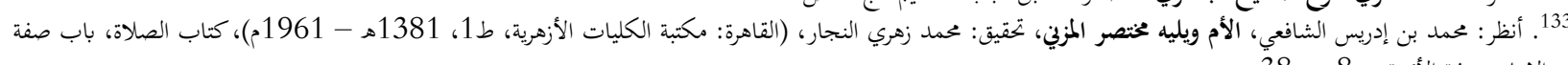

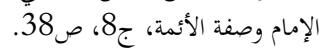


ولأجل اهتمام بالغة يُوجد عديد من الروايات تبيّن كل مجالات الحضور إلى المسجد على حدة. فبيّن الاستعداد

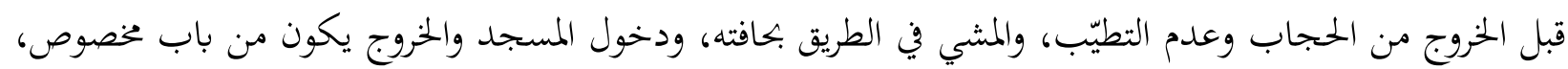
وإقامة الصلاة في صف مخصوص ثم المغادرة في أسرع وقت. وجميع هذه الأحاديث تبلغ القضية إلى حد التواتر بالمعنى بأن المرأة تشهد الجماعة في المسجد. المجتمع القارة الهندية يحتاج إلى فتح الذريعة بدلاً من سدّها حول هذه القضية. وقد رسم الباحث عديد من الأسباب

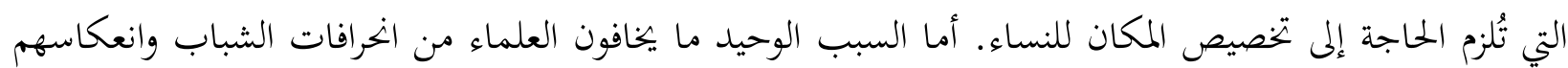

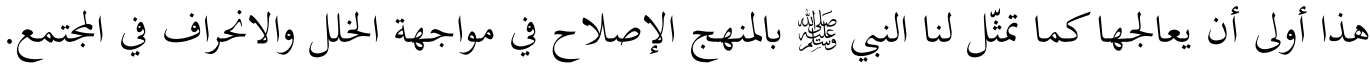




\section{المصادر والمراجع}

Syed Mahmudul Hasan and Sa'duddin Mansoor, "Salat al-Nisa fi al-Masjid fi Bangladesh

bayna al-Shar'I wa al-Tatbiq; Dirasah Muqarana Tahliliyyah”, Journal of al-Risalah, 2,4 (2018).

إبراهيم بن صالح الخضيري. أحكام المساجد في الشريعة الإسلامية. المملكة العربية السعودية: وزارة الشئون الإسلامية

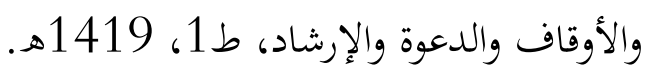

ابن أبي شيبة، عبد الله بن محمد بن إبراهيم أبي شيبة العبسي أبو بكر. مصنف ابن أبي شيبة. تحقيق: حمد بن عبد الله

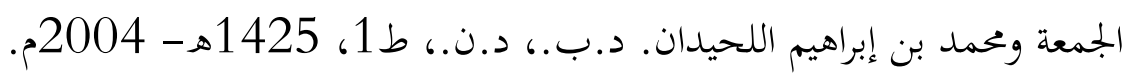

ابن الأثير الجزري. جامع الأصول في أحاديث الرسول. تحقيق: عبد القادر الأرناؤوط. مصر: مكتبة الحلواني - مطبعة

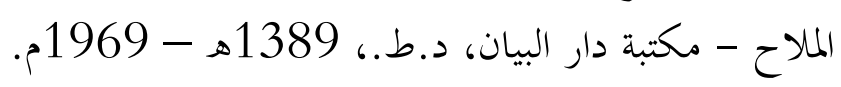

ابن بطال، أبو الحسن علي بن خلف بن عبد الملك بن بطال البكري القرطبي. شرح صحيح البخارى. تحقيق: أبو

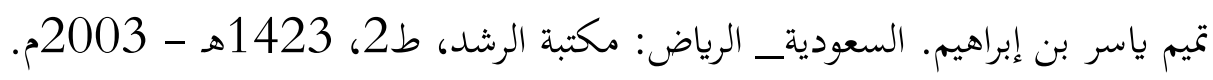

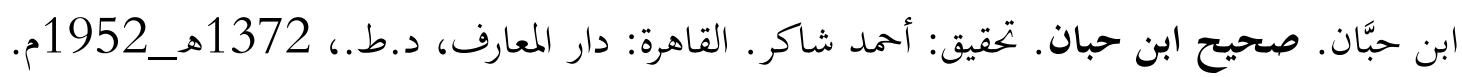
ابن رجب الحنبلي. فتح الباري شرح صحيح البخاري. تحقيق: أبو معاذ طارق بن عوض الله بن محمد. دار ابن

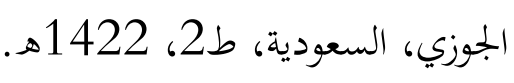

أبو العباس ضياء الدين أحمد بن عمر القرطبي. المفهم لما أشكل من تلخيص كتاب مسلم. بيروت: دار ابن كثير،

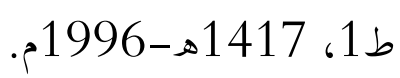
أبو الفداء إسماعيل بن عمر بن كثير القرشي الدمشقي. تفسير القرآن العظيم. تحقيق: سامي بن محمد سلامة. رياض:

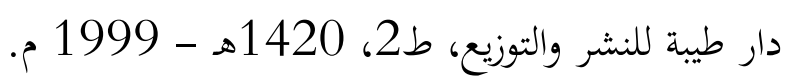

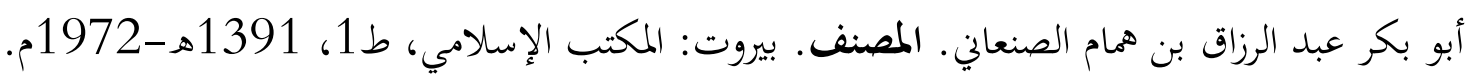
أبو زكريا محيي الدين يجيى بن شرف النووي. المنهاج شرح صحيح مسلم بن الحجاج. بيروت: دار إحياء التراث العربي، ط2، 1392هـ

أبو عبد الرحمن أحمد بن شعيب بن علي الخراساني. السنن الصغرى. تحقيق: عبد الفتاح أبو غدة. حلب: مكتب

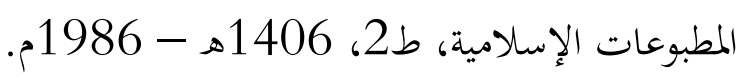

أبو عمر يوسف بن عبد الله بن محمد بن عبد البر. التمهيد لما في الموطأ من المعالي والأسانيد. القاهرة: مكتبة ابن تيمية، د.ط.، د.ت دوبن

أبو نعيم، أحمد بن عبد الله بن أحمد بن إسحاق بن موسى بن مهران الأصبهاني. المسند المستخرج على صحيح

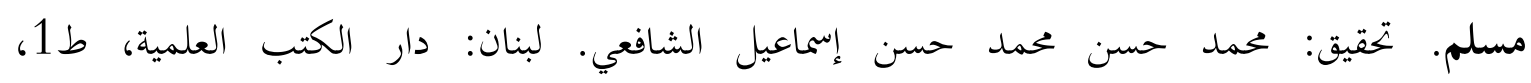

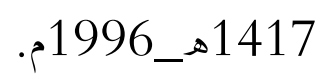

أحمد بن علي بن حجر العسقلاني. فتح الباري بشرح صحيح البخاري. تحقيق: عبد القادر شيبة الحمد. طبع على

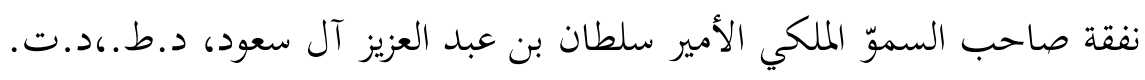


أحمد بن غانم بن سالم ابن مهنا، شهاب الدين النفراوي الأزهري المالكي. الفواكه الدواني على رسالة ابن أبي زيد

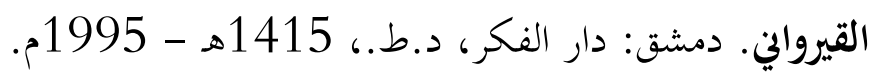

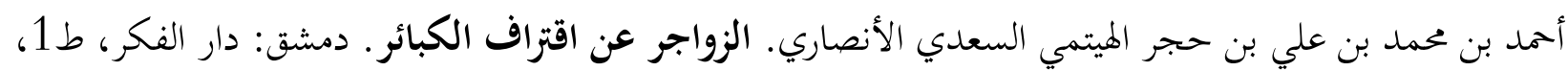
1407هـ-1987م.

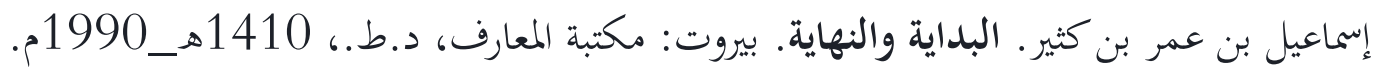

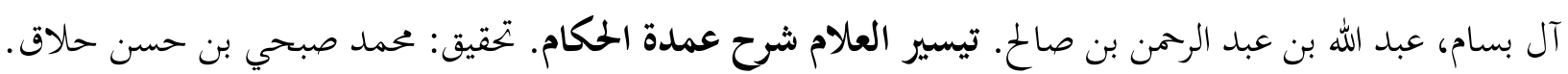

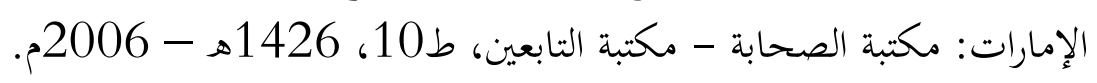

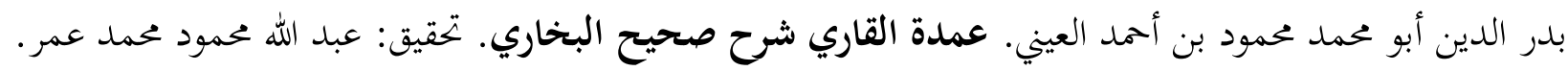

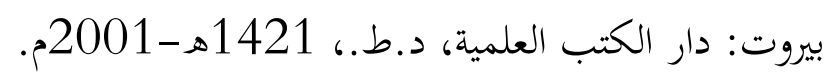

جاسر عودة. المرأة في المسجد... دورها ومكانها وأحكامها. بحث مقدم للمجلس الأوروبي للإفتاء والبحوث في دورته

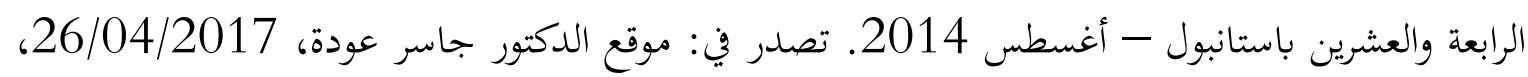

http://www.jasserauda.net/portal/

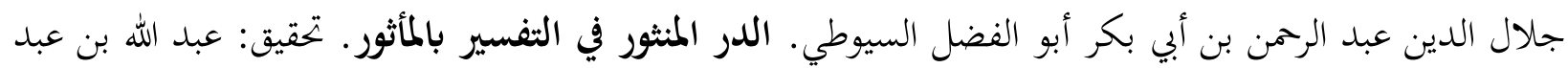

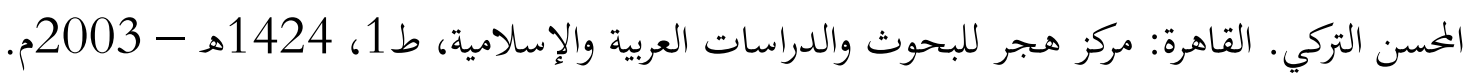

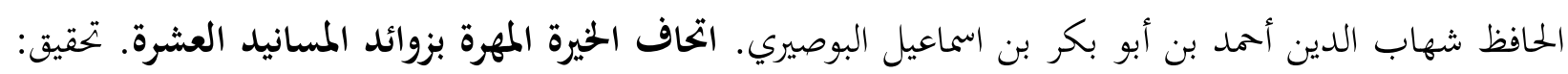

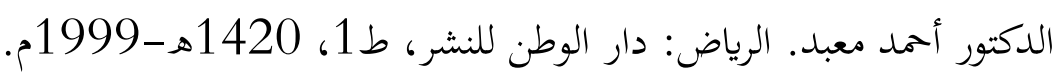

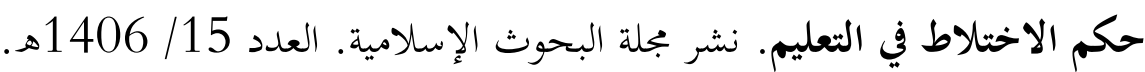

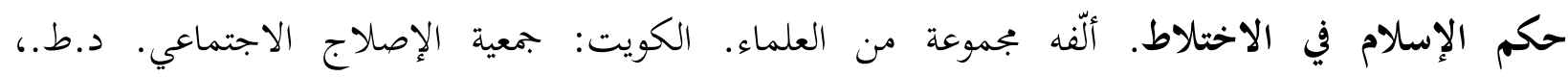
1389هـ_1969م.

دروس صوتية. الشيخ مصطفى العدوي. موقع الشبكة الإسلامية. تاريخ المشاهدة: 15-10-2018، تصدر

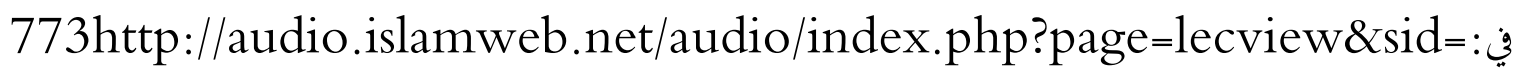
الدكتور محمد ضياء الرمن الأعظمي. المنّة الكبرى شرح وتخريج السنن الصغرى للحافظ البيهقي. الرياض: المكتبة

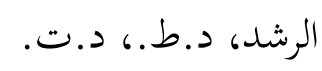

زين الدين أبي الفرج عبد الرحمن ابن شهاب الدين بن رجب البغدادي ثم الدمشقي. فتح الباري لابن رجب. تحقيق :

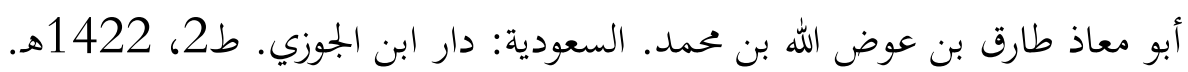

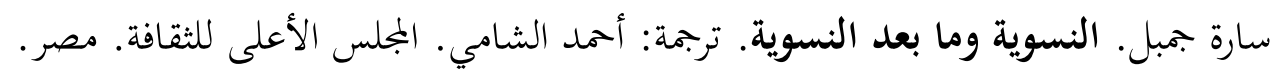

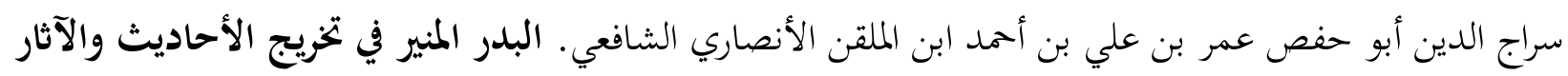

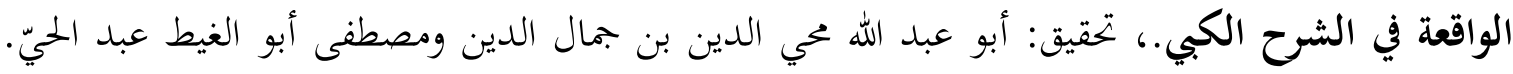

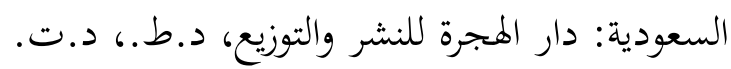

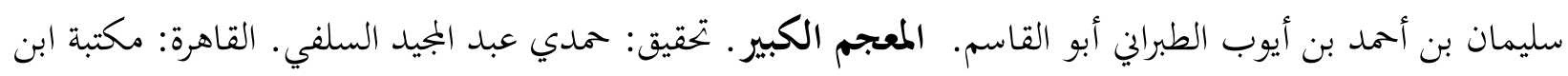
تيمية، د.ط.، د.ت. 
سليمان بن الأشعث الأزدي السجستاني. سنن أبي داود. تحقيق: شعيب الأرناؤوط وآخرون. بيروت: دار الرسالة

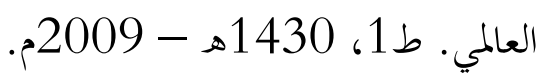

سليمان بن داود بن الجارود الطيالسي البصرى. مسند أبي داود الطيالسي. تحقيق: الدكتور محمد بن عبد المحسن

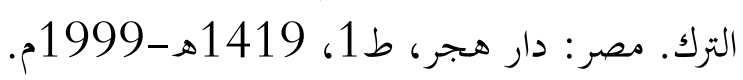

سيد محمود الحسن. حديث عائشة في منع النساء من المساجد: نقاش علماء بنغلاديش حوله. مجلة دراسة القرآن والحديث، العدد: 9-1، يونيو، 2020.

الشنقيطي، محمد الأمين بن محمد المختار. أضواء البيان في إيضاح القرآن بالقرآن ومعه التتمة. السعودية: المؤسسة

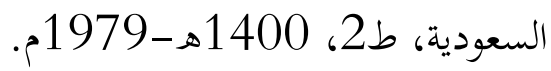

الشيخ محمد بن عبد الرحمن المغواري. فتح البرّ في الترتيب الفقهي لتمهيد ابن عبد البّّ. الرياض: بجموعة التحف

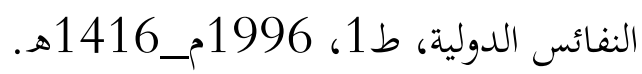

ص 227.

صالح بن فوزان الفوزان. الملخص الفقهي. نشرت في بجلة معرفة السنن والآثار العلمية، د.ع.، د.ت. ل)، تاريخ الكتابة:

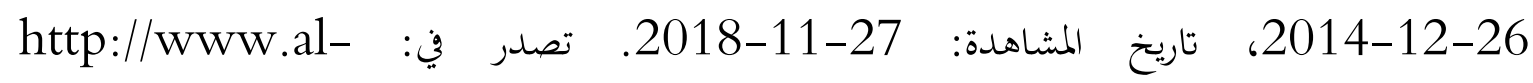

.html10523sunan.org/vb/archive/index.php/t-

عبد العزيز بن باز ومحمد بن صالح العثيمين. فتاوى مهمة. تحقيق: إبراهيم الفارس. الرياض: دار العاصمة، ط1، 1413

عبد العزيز بن عبد الله بن باز. حكم تطيب المرأة عند خروجها. نشرت في المجلة العربية (بجلة شهرية) في العدد (168)

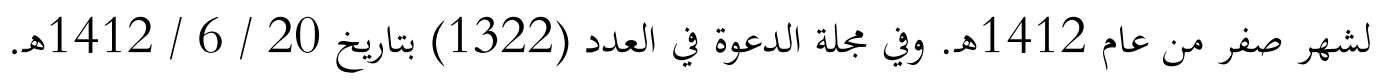

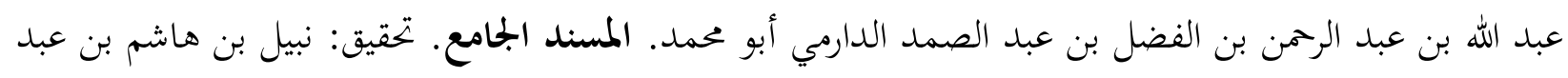

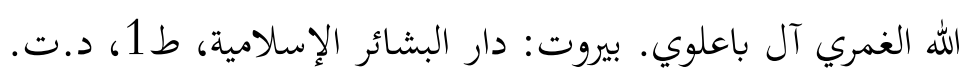

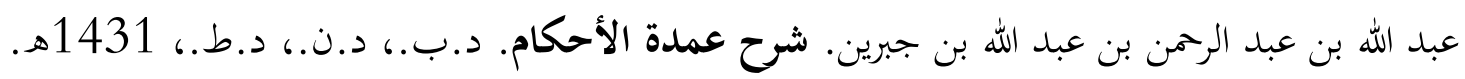

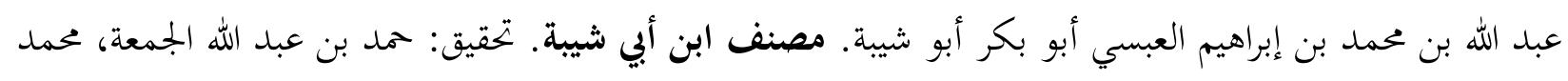

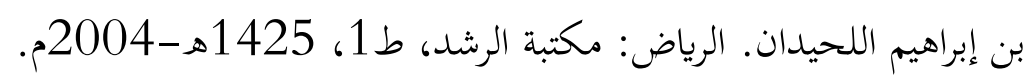

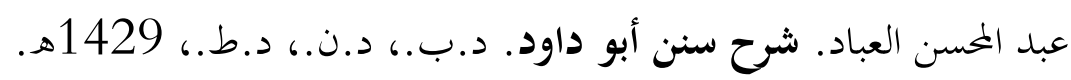

عبد بن حميد. المنتخب من مسند عبد بن حميد. تحقيق: مصطفى العدوي. الرياض: دار بلنسية، ط2، بكن، 1423هـ 2002

علي بن أبي بكر الهيثمي نور الدين. موارد الظمآن إلى زوائد ابن حبان. تحقيق: حسين سليم أسد الداراني، عبده علي

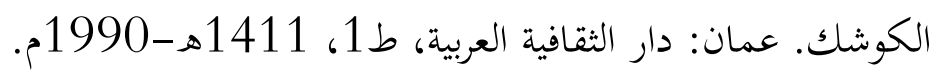

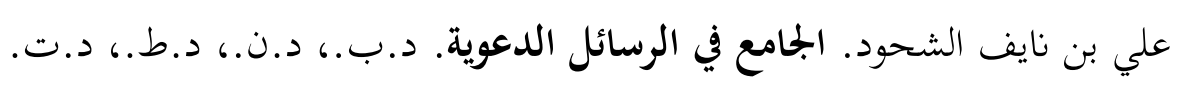

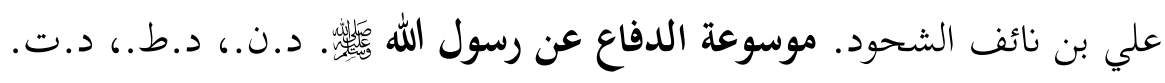

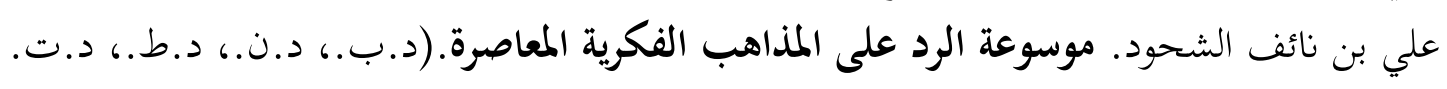




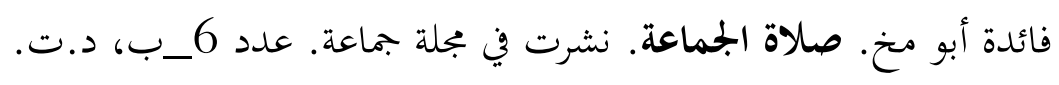

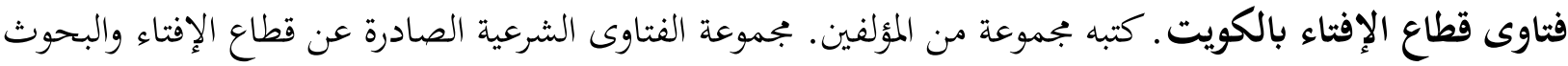

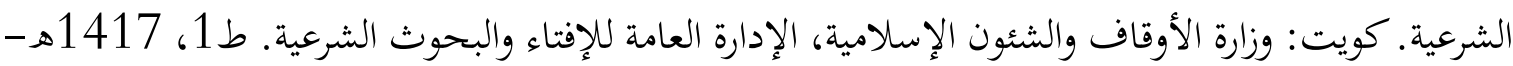

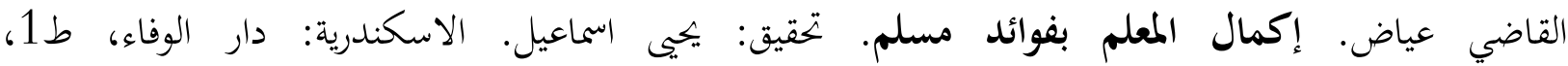

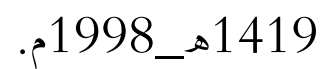

مالك بن أنس. موطأ مالك. تحقيق: محمد فؤاد عبد الباقي. بيروت: دار إحياء التراث العربي. د.ط.، 1406هـ-

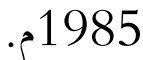

جمموعة من المؤلفين. الموسوعة الفقهية. كويت: دار الصفوة، وزارة الأوقاف والشئون الإسلامية، ط1، 1418هـ-

محمد أمين بن عمر بن عبد العزيز عابدين الدمشقي الحنفي. رد الختتار على الدر المختار (حاشية ابن عابدين).

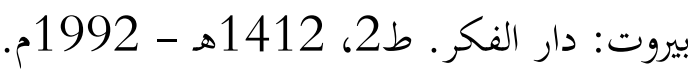

محمد بن إدريس الشافعي. الأم ويليه مختصر المزني. تحقيق: محمد زهري النجار. القاهرة: مكتبة الكليات الأزهرية،

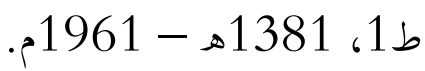

محمد بن اسحاق بن خزيمة أبو بكر السلمي النيسابوري. صحيح ابن خزيمة. تحقيق: د. محمد مصطفى الأعظمي.

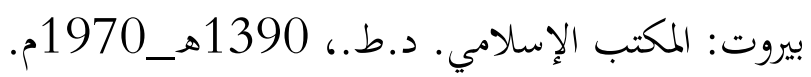

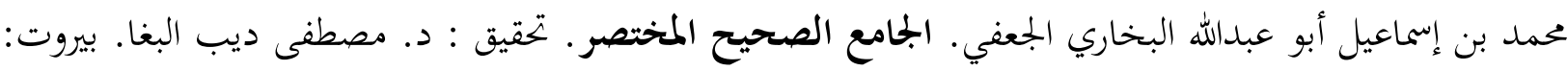

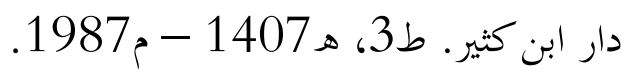

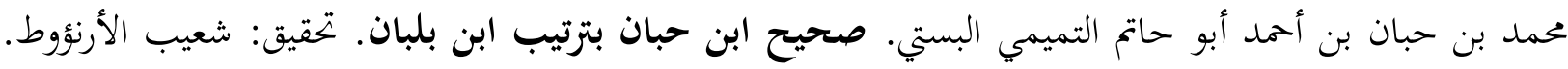

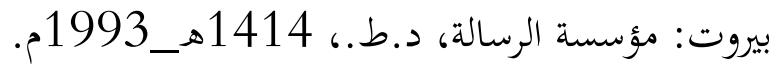

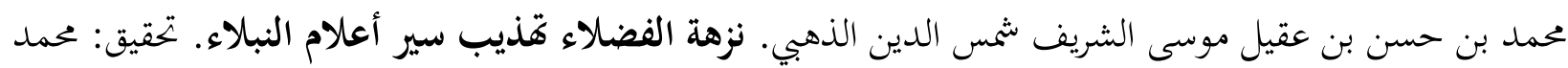

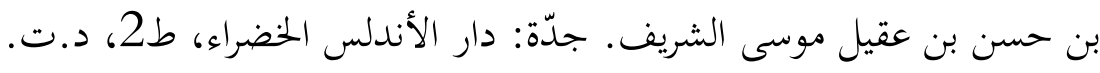

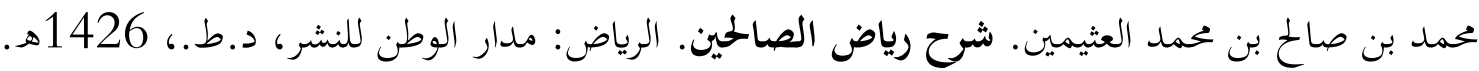

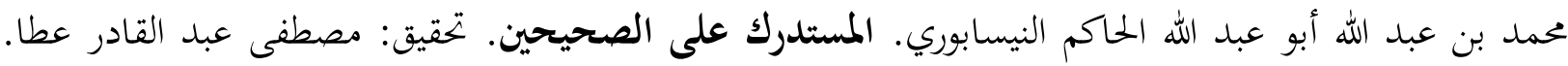

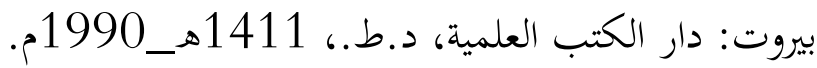

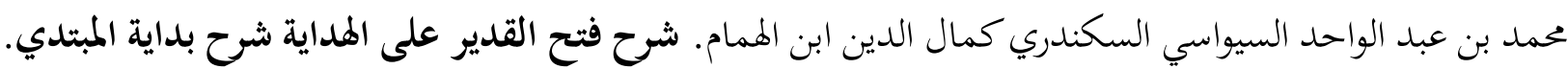

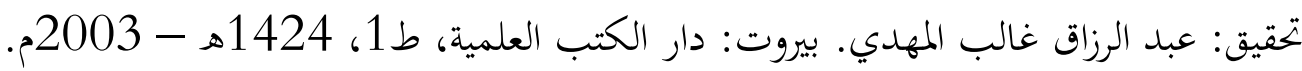

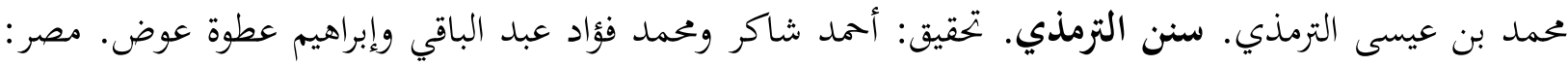

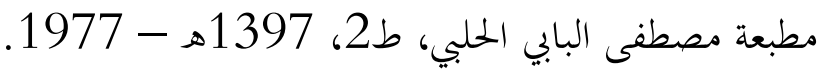

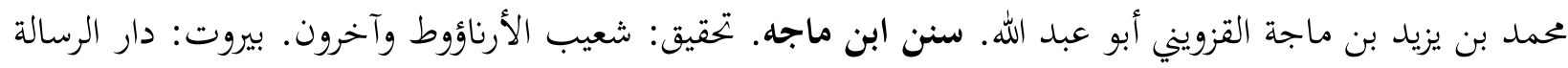

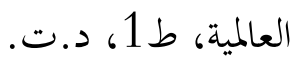


محمد شمس الحق العظيم آبادي. عون المعبود. بروت: دار الفكر، د.ط.، 1415هـ - 1995م.

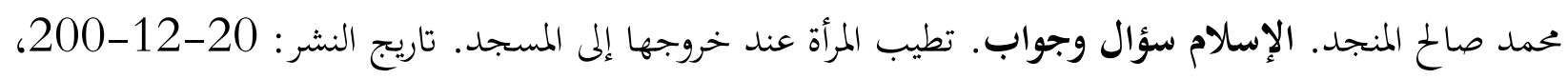

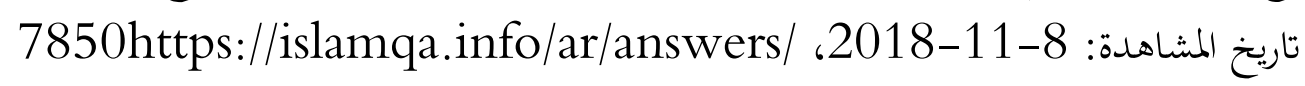

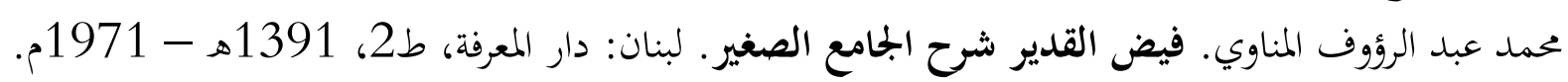

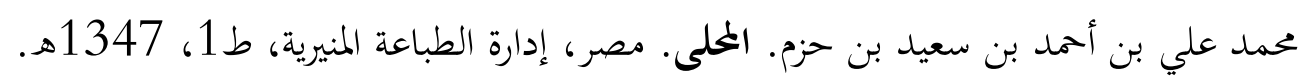

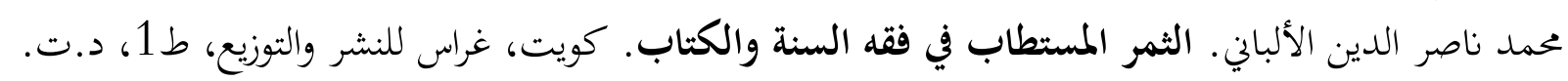

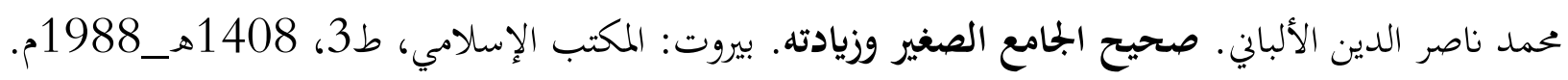

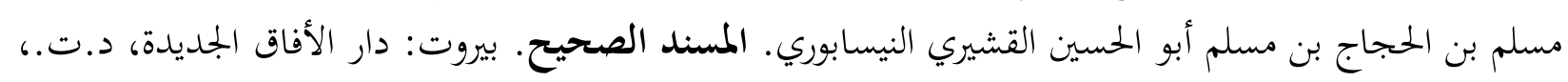
b.د

ملا علي القاري. نور الدين ملاعلي بن سلطان محمد الهروي القاري. مرقاة المفاتيح شرح مشكاة المصابيح. بيروت:

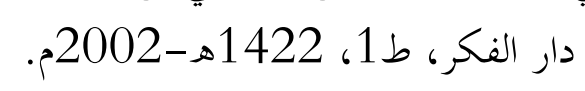

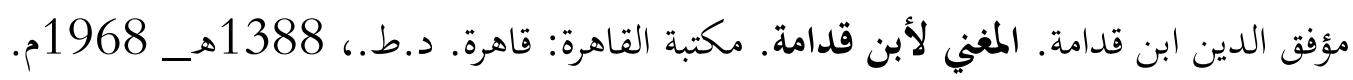

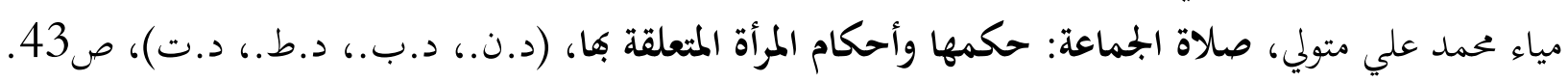

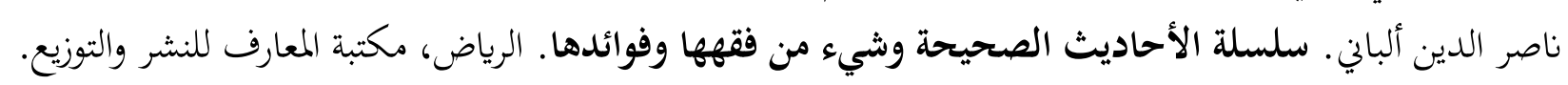

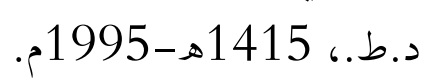

يعقوب بن اسحاق أبو عوانة الأسفرائني. مسند أبي عوّانة. تحقيق: أيمن بن عارف الدمشقي. بيروت: دارامعرفة، ط1 1415،

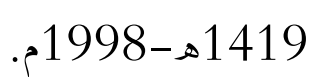
يوسف بن الزكي عبد الرحن أبو الحجاج المزي. تحذيب الكمال. بيروت: مؤسسة الرسالة، د.ط.، 1400هـ_1980م. 